\title{
Classification of renal cell tumors - current concepts and use of ancillary tests: recommendations of the Brazilian Society of Pathology
}

\author{
Daniel Abensur Athanazio ${ }^{1,2^{*}}$ (D, Luciana Schultz Amorim ${ }^{3}$, Isabela Werneck da Cunha ${ }^{4}$, Katia Ramos Moreira Leite ${ }^{5}$, \\ Alexandre Rolim da Paz ${ }^{6,7}$, Regina de Paula Xavier Gomes ${ }^{8,9,10}$, Fabio Rocha Fernandes Tavora ${ }^{11,12}$, \\ Sheila Friedrich Faraj ${ }^{13,14}$, Marcela Santos Cavalcanti ${ }^{15,16}$ and Stephania Martins Bezerra ${ }^{17}$
}

\begin{abstract}
Classification of renal cell carcinomas has become more challenging. The 2016 WHO classification included 14 different subtypes and 4 emerging/provisional entities, and recent literature indicates new entities to be incorporated. Nomenclature is based on cytoplasmic appearance, architecture, combination of morphologies, anatomic location, underlying disease, familial syndromes, and specific genetic alterations. Immunohistochemistry is useful in selected cases while it can be insufficient in entities that require molecular confirmation of a specific gene alteration. The aim of these recommendations is to provide a reasonable and optimized approach for the use of ancillary tests in subtyping renal tumors, particularly in resource-limited settings.
\end{abstract}

Keywords: Carcinoma, renal cell, Pathology, molecular, Immunohistochemistry, Classification

\section{Background}

Renal cell carcinomas (RCCs) encompass $1-3 \%$ of human malignancies and $75-80 \%$ of adult kidney cancers. Pathologic classification of renal carcinomas is complex, and nomenclature is based on cytoplasmic appearance, architecture, combination of morphologies, anatomic location, underlying disease, familial syndromes and specific genetic alterations. The current 2016 World Health Organization classification includes 14 subtypes and 4 emerging/provisional entities. Additional emerging entities recently described in the literature will probably be incorporated in future classifications.

Classifications are instinctive in biological science and can be central to how knowledge evolves towards diagnosis

\footnotetext{
* Correspondence: dathanazio@gmail.com

${ }^{1}$ Hospital Universitário Professor Edgard Santos / Universidade Federal da Bahia, Salvador, Brazil

${ }^{2}$ Imagepat, Laboratory of Pathology, Salvador, Brazil

Full list of author information is available at the end of the article
}

and treatment of diseases. In cancer, it can also be viewed as a way of cataloging evolutionary trajectories of complex genomes. In times of globalization and big data acquisition, large cohorts have revealed not only biological diversity within known entities, but also previously unrecognized ones. However, official incorporation of new entities requires clinical, histopathologic, and/or molecular defining features, in addition to diagnostic reproducibility.

Despite the considerable advances in molecular characterization of renal cell carcinomas, these tumors are still classified mainly by morphology and immunohistochemical features in the major reference centers worldwide. As detailed below, there is a growing effort to translate key molecular features to immunohistochemistry (e.g, MiT family translocation, fumarate hydratase deficiency, succinate dehydrogenase deficiency). In places with limited access to molecular resources and specific immunohistochemical markers, such as in many Brazilian regions, pathologists may face

(c) The Author(s). 2021 Open Access This article is licensed under a Creative Commons Attribution 4.0 International License, which permits use, sharing, adaptation, distribution and reproduction in any medium or format, as long as you give appropriate credit to the original author(s) and the source, provide a link to the Creative Commons licence, and indicate if changes were made. The images or other third party material in this article are included in the article's Creative Commons licence, unless indicated otherwise in a credit line to the material. If material is not included in the article's Creative Commons licence and your intended use is not permitted by statutory regulation or exceeds the permitted use, you will need to obtain permission directly from the copyright holder. To view a copy of this licence, visit http://creativecommons.org/licenses/by/4.0/. 
difficulties in standardizing an optimal algorithm to classify renal cell carcinomas. Limitations may pertain to financial limitations to proper diagnostic work up or availability of a wide array of genetic tests. Therefore, it is important to value morphology as the first diagnostic driver, in order to narrow down the differential as much as possible using basic tools. The aim of these recommendations is to provide a reasonable approach for the use of ancillary tests in subtyping renal cell tumors. This set of recommendations is endorsed by the Brazilian Society of Pathology - Clube de Patologia Urológica (Genitourinary Pathology Club).

\section{Tumors with predominant clear cells}

Clear cell renal cell carcinoma encompasses $70 \%$ of renal cell carcinomas. It occurs in sporadic form in 95\% of all cases and a minor part of them are associated with von Hippel-Lindau disease and other familial syndromes. The typical morphology of tumor cells is clear or granular cytoplasm (due to accumulation of lipid and glycogen) which gives a typical yellow appearance at gross examination. Architecture may be acinar, nested, alveolar, tubular, solid/cords, and small cysts. A delicate network of capillary vessels is intimately associated with the tumor (Fig. 1a). Clinical behavior is dependent on the presence of high-grade areas, higher stages, presence of necrosis, and sarcomatoid/rhabdoid morphology. One third of localized disease will developed metastasis during oncologic follow up. Half of patients who developed a post-nephrectomy recurrence will die of the disease (Moch et al. 2016).

There are no specific marker of clear cell RCC but the typical immunophenotype includes strong and diffuse complete membranous staining for carbonic anhydrase IX (CA-IX) and positivity for RCC antigen (both more common in low grade areas), CD10 positivity (although not specific) and vimentin staining (more common in high-grade areas) (Reuter et al. 2014). Cytokeratin 7 (CK7) is usually negative or only focally positive in clear cell RCC. Of notice, high-grade areas commonly show eosinophilic (non-clear) cytoplasm with CK7 positivity. Since no markers is specific, a panel including these antibodies are warranted for differential diagnosis specially with chromophobe carcinoma. Such distinction is of interest due to inherent differences in biologic behavior of high-grade clear cell and chromophobe RCC, as well as possibility of distinct genetic background and differences in treatment protocols of advanced disease.

Recent consultation conference by the International Society of Urologic Pathology (ISUP) emphasized CA-IX

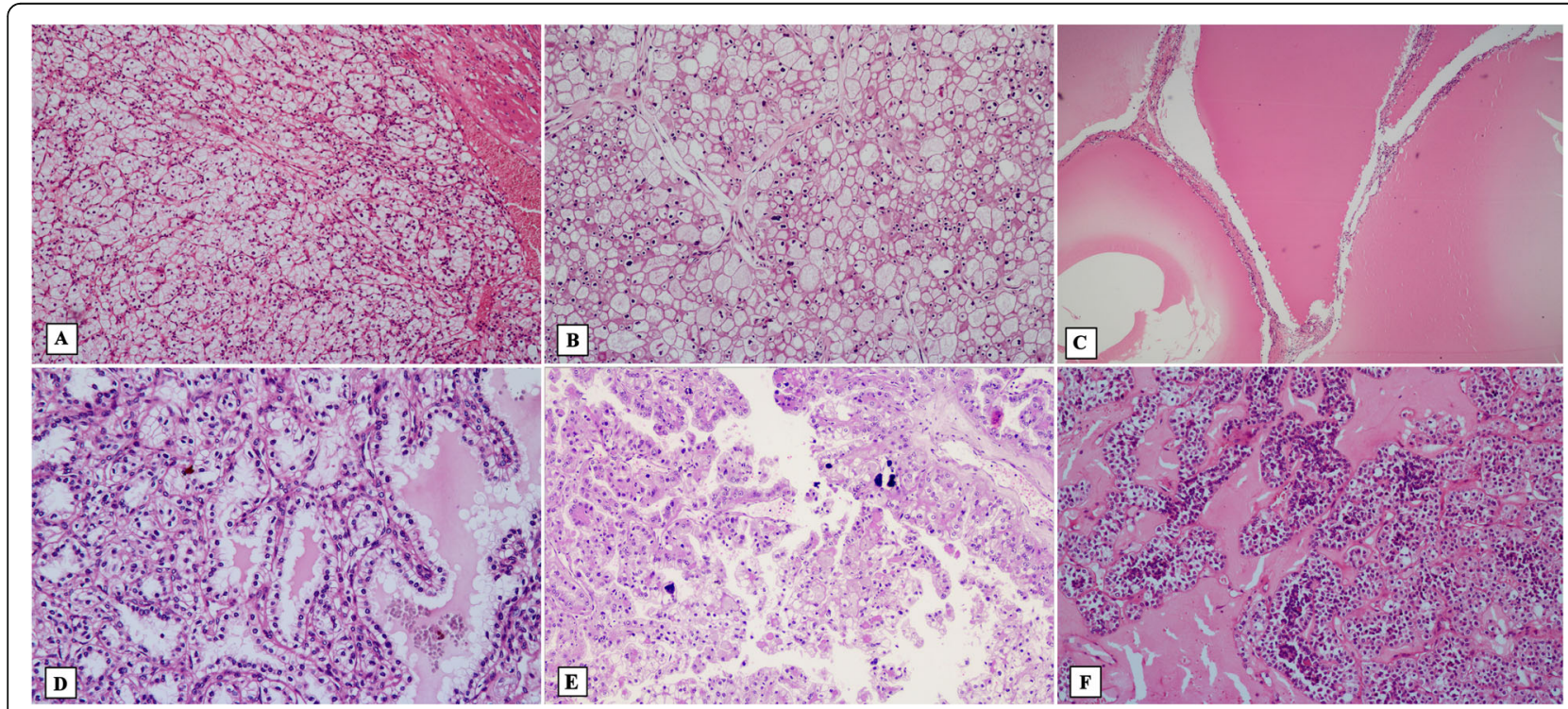

Fig. 1 Renal cell carcinomas with "clear cells". (Conventional) Clear cell carcinoma showing typical low-grade areas with nests, acini and cords of clear cells intermixed with a delicate network of capillary vessels (a HE, 100x). Chromophobe carcinoma typically shows sheets of cells separated by incomplete septations. Large eosinophilic cells (oncocytoma-like) commonly coexist with vegetal-like cells (with distinct cytoplasmic membrane). Typical morphology includes wrinkled ("rasinoid") nuclei and perinuclear halos (b HE, 100x). Multilocular cystic renal neoplasm of low malignant potential shows cystic spaces with delicate septae lined by low-grade clear cells. No expansive growth are observed within septae (c HE, 40x). Clear cell papillary carcinoma typically exhibits tubular and papillary architecture with cuboidal or columnar clear cells and low-grade nuclei uniformly arranged away from the basement membrane ("piano-key-like" pattern) (d HE, 100x). MiT family translocation (Xp11 / TFE3) carcinoma has mixed patterns, but a characteristic feature is the papillary morphology with intermixed clear and eosinophilic cells with highgrade nuclei and the presence of small calcified bodies (e HE, 100x). MiT family translocation $(T(6 ; 1)$ / TFEB) carcinoma's most distinctive pattern is of a biphasic tumor with large epithelioid cells in the periphery and smaller cell in the center of large nests clustering around basement membrane deposits (f $\mathrm{HE}, 100 \mathrm{x}$ ) 
immunohistochemistry as the best available surrogate marker for genetic alterations specific of clear cell carcinoma (downstream pathway of VHL signaling) (Williamson et al. 2020). CA-IX expression is useful for the diagnosis of clear cell RCC but several limitation are of relevance: 1) it may be expressed in carcinomas of other primary sites (such as breast and gastric carcinomas); 2) only complete membranous pattern with diffuse distribution is specific of clear cell type among RCCs; 3 ) focal expression - mainly in the vicinity of ischemia/necrosis areas - may be seen in any renal tumor (since its expression is activated by hypoxia/VHL pathway) (Williamson et al. 2020). In the context of a presumptive diagnosis of a primary renal cell carcinoma, even in the metastatic setting, diffuse membrane staining of CA-IX is supportive of clear cell type - which is important to guide therapeutic options (Fig. 2).

The differential diagnosis between of high-grade clear cell carcinoma and chromophobe is easier when a lowgrade area of clear cell carcinoma component is identified. When true hybrid clear cell - chromophobe are observed, this should raise concern for Birt-Hogg-Dubé syndrome and test for the folliculin (FLCN) gene germline mutation (Zhou and Magi-Galluzi 2015). A combination of morphologies may also be observed in MiTfamiliy translocation RCCs, specially Xp11 (TFE3) subtype and immunohistochemistry and/or FISH analysis for this tumor may be considered (Kuroda et al. 2020; Kuthi et al. 2020). If these genetic alterations are excluded, a combination of morphologies of renal cell carcinomas is an indication for the diagnosis of unclassified subtype of renal cell carcinoma - and prognosis can be estimated based on grade, stage, necrosis, and presence of sarcomatoid and rhabdoid morphology (Moch et al. 2016).

The most common genetic alterations in clear cell RCCs are deletion of short arm of chromosome 3 and inactivation/mutation of VHL gene. It is usually not required to perform genetic testing for the diagnosis of clear cell RCC (Williamson et al. 2020). Germline mutation testing in early onset (under age 46) kidney cancer is recommended for patients with bilateral, multifocal disease and those with a family history of kidney cancer. Testing VHL gene is recommended for those who have either a family history of VHL or a VHL clinical phenotype (i.e., bilateral renal cysts/tumors, pancreatic neuroendocrine tumors, retinal angiomas, hemangioblastomas of the central nervous system). For patients with familial clear cell RCC, we recommend testing for VHL, SDHC, BAP1, TSC1 and TSC2 (Linehan 2013). Recently, ISUP consultation conference suggested germline VHL mutation testing in patients with clear cell RCC that are microscopic; multifocal or associated with multifocal cysts; or diagnosed in younger than 46 years (Williamson et al. 2020).

We discuss below how to distinguish it from other RCC subtypes with predominant clear cells. Aside from clear cell cytology, tumor and vascular architecture are

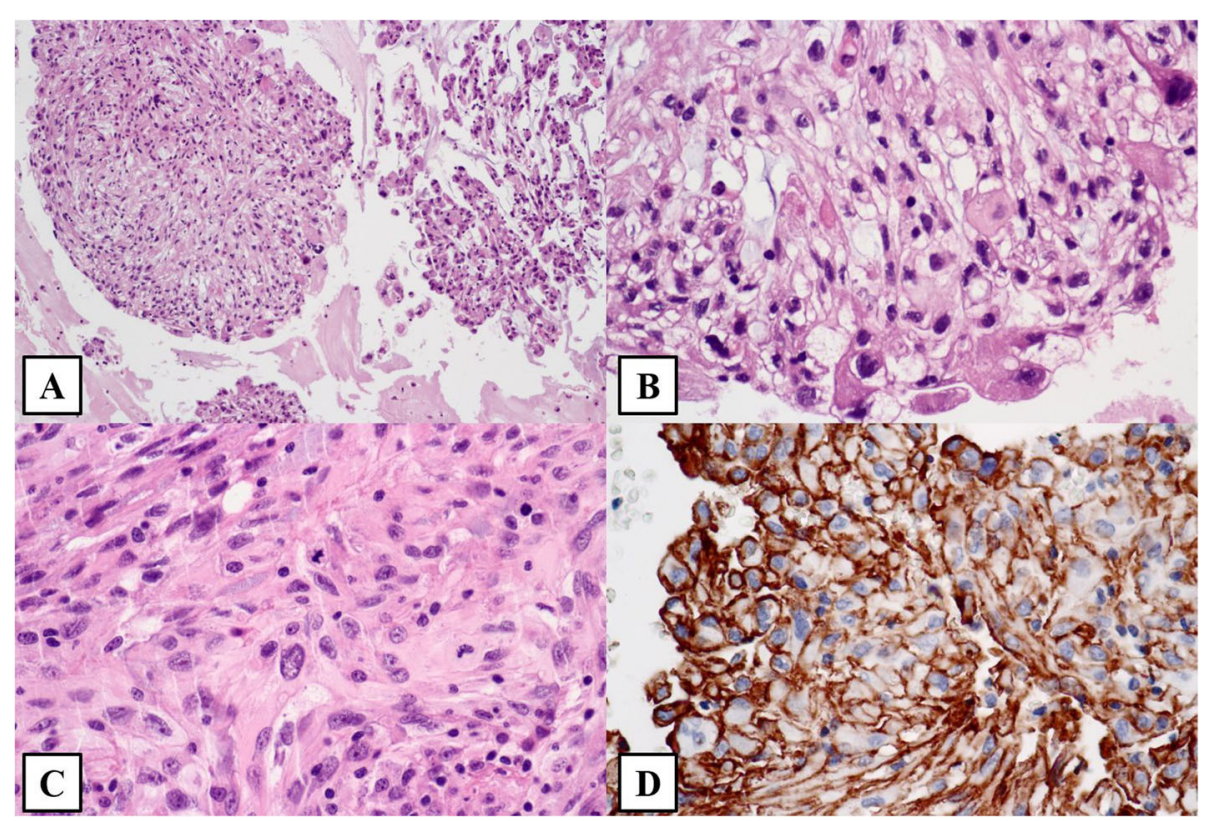

Fig. 2 A metastatic carcinoma in the brain of a 68-year old female patient with a not biopsied kidney mass. It has minute areas of cytoplasmatic clearing (a and $\mathbf{b}$ HE stain at 100x and 400x magnification). Most of the tumor showed, however, sarcomatoid morphology (c HE stain, 100x). Pan-cytokeratin and PAX8 were diffusely positive. When a kidney primary is considered, the expression of carbonic anhydrase IX in membranous and diffuse pattern is specific for clear cell subtype (d 400x) 
important distinctive features of (conventional) clear cell RCC. It usually shows solid and nests or variable sizes which are separated by intricately dividing vascular septae that surround the cell nests. Such typical pattern may be obscured by necrosis, cystic transformation, fibrous scar, high-grade eosinophilic cell predominant areas, and rhabdoid/sarcomatoid areas. On the other hand, even the focal presence of such architecture in a biopsy is sufficiently diagnostic of clear cell RCC. Since nested, alveolar and solid clear cell areas may be also seen MiT family translocation RCC and epithelioid angiomyolipoma - ancillary immunohistochemistry may be performed when these diagnoses are considered (see below) (Tickoo et al. 2015).

Chromophobe RCC with prominent "clear" cells typically shows sheets of cells separated by incomplete septations. The presence of cells with wrinkled nuclei, perinuclear halos, and prominent cell membranes often helps in this diagnosis (Fig. 1b). When considering this differential, immunochemistry may be helpful to distinguish clear cell RCC (carbonic anhydrase IX strong, diffuse and with a membranous pattern; CD10, RCC antigen, and vimentin positive) and chromophobe RCC (c-KIT and cytokeratin 7 positive). Chromophobe carcinoma may also enter in the differential diagnoses of renal tumor with predominant eosinophilic cells and is further discussed below.

Multilocular cystic renal neoplasm of low malignant potential is the term suggested by Suzigan et al. (2006) and adopted by WHO in 2016 to rename multilocular cystic RCC based on the experience that none of the tumors with available follow up showed recurrences or metastasis (Moch et al. 2016). It comprises less than $1 \%$ of resected renal tumor and is usually diagnosed as incidental finding in imaging exams. The gross appearance is of cysts with variable sizes separated by delicate septae. The cysts are lining by cells with clear cytoplasm and low-grade (ISUP 1 or 2) nuclei (Fig. 1c). The septae between cysts may contain some cords of clear cell but the presence of expansive nodules (solid growth) within septae exclude this diagnosis and the pathologist must considered a regression form (cystic degeneration) of clear cell carcinoma (Epstein and Netto 2014). More recently, it has been suggested that some of these tumors with papillary or solid growths (intracystic or intraseptal) are indeed cystic forms of clear cell papillary RCC, and still behaves in an indolent manner. For this diagnosis, typical cytological and immunohistochemical findings are required - see discussion below (Brimo et al. 2016).

Table 1 reviews key recommendations for nonpapillary tumors with predominant clear cells.

Several renal cell tumors may present with focal or diffuse papillary architecture. Conventional clear cell RCC may commonly show tubular and focal papillary architecture. However, the presence of diffuse tubular, tubulopapillary, or papillary architecture with clear cell cytology should prompt the pathologist to consider other differential diagnoses, including clear cell papillary RCC, papillary RCC, MiT family translocation RCC; or unclassified RCC (Tickoo et al. 2015).

Clear cell papillary RCC is a subtype of RCC included in the 2016 WHO classification first described in kidneys with end-stage renal disease (Tickoo et al. 2006). Some authors prefer the term clear cell "tubulopapillary" RCC, while not recommended from 2016 WHO blue book, to emphasize the (commonly) predominance of tubular rather than papillary architecture. It is important to recognize this subtype because - even if clear cell and papillary growth are typical findings - this tumor follows an indolent course, and no metastasis have been reported (Kuroda et al. 2014; Massari et al. 2018). It shows a much better prognosis than (conventional) papillary and clear cell RCCs. Clear cell papillary RCC accounts for $1-4 \%$ of all resected renal tumors. It occurs in sporadic forms an in association with end-stage renal disease (Giunchi et al. 2020). This tumor is usually diagnosed as low-stage, and are well-circumscribed nodules with a mean size of less than $3,0 \mathrm{~cm}$. They are usually low grade (ISUP grade 1 or 2), and higher grade should suggest other subtypes in the differential diagnosis (Mai et al. 2008; Aydin et al. 2010; Adam et al. 2011; Aron et al. 2015). Tumor necrosis, perineural invasion and lymphovascular invasion have not been observed (Moch et al. 2016).

Growth patterns may be a variable mixture of tubular (commonly predominant), papillary, acinar, cystic, cords and solid. The typical cytology is of cuboidal or columnar cells with clear cytoplasm and nuclei uniformly arranged away from the basement membrane ("piano-keylike" pattern) (Moch et al. 2016) (Fig. 1d). When a small nodule shows the typical architecture, grade, and cytologic findings, no immunostains or additional tests are required for the diagnosis. It is important, however, to emphasize that this tumor should be diagnosed with caution in biopsies. In addition, some tumors may have overlapping features with conventional clear cell carcinoma. These include a combination of discrete areas of both clear cell RCC and clear cell papillary RCC within the same neoplasm. In these cases, immunohistochemistry can help in this differential diagnosis based on cytokeratin 7 expression (strong and diffuse in clear cell papillary RCC) and anhydrase carbonic IX expression and pattern (basolateral or "cup-shape"-like distribution in clear cell papillary, and complete membranous pattern in the conventional clear cell. In cases where both morphology and immunoprofile suggest the presence of both subtypes, the diagnosis of clear cell carcinoma is recommended (Dhakal et al. 2016). 


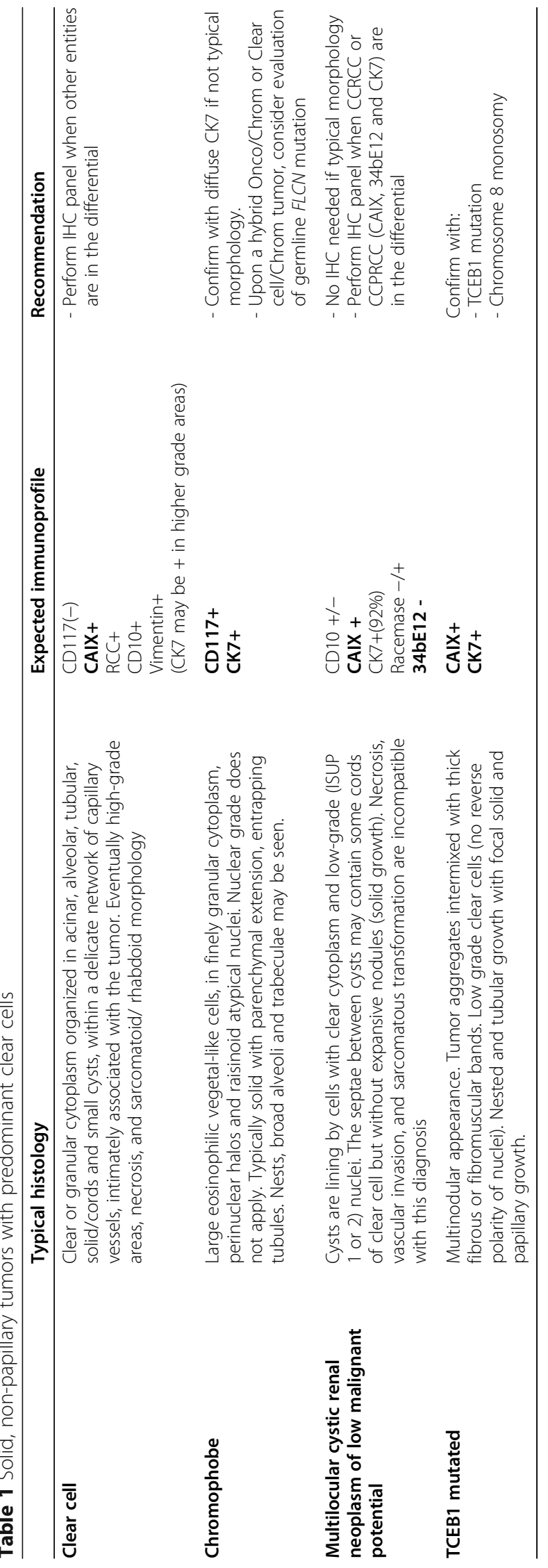


GATA3 is usually positive (76\%) in clear cell papillary RCC (Mantilla et al. 2017). Therefore, GATA3 should not automatically indicate urothelial differentiation. Such overlapping features are of interest because a panel of cytokeratin 7, GATA3, and PAX8 may not differentiate papillary tumors such as papillary, clear cell RCC, nephrogenic adenoma, and urothelial neoplasms. Up to $40 \%$ of nephrogenic adenomas may express GATA3 (McDaniel et al. 2014), and about $20 \%$ of urothelial carcinomas of the upper urinary tract are PAX8 positive (Reuter et al. 2014). The diagnosis should rely on morphology, location (as clear cell RCC are typically centered in the cortex), and clinical history (previous trauma is usually associated with nephrogenic adenoma). A careful gross examination is crucial because some clear cell papillary renal RCCs are predominantly cystic (Brimo et al. 2016) and intracystic epithelial proliferation may macroscopically resemble origin in dilated pyelocaliceal system.

Among patients with von Hippel-Lindau syndrome, tumors with similar features of clear cell papillary RCC usually show an immunophenotype typical of (conventional) clear cell carcinomas and are better classified as such (Williamson et al. 2020).

MiT family translocation RCC usually shows a mixture of clear and eosinophilic cells. Many cells often appear voluminous or ballooned out with occasional psammoma bodies and eosinophilic hyaline nodules. Clear cell lining papillae and biphasic nests with large peripheral and central small cells may suggest Xp11 and $\mathrm{t}(6 . ; 11)$ translocations, respectively, and should warrant the pathologist to seek further studies (Fig. 1 e and f). Documentation of specific translocations and/or protein expression is required for the diagnosis. Tumors with a variable proportion of clear cells and papillary architecture and other features suggestive of MiT translocation RCCs - but no immunohistochemical or FISH evidence of TFE3 or TFEB translocations - should be, however, diagnosed as unclassified RCC.

It is well-known that conventional clear cell RCC may also show, albeit rarely, a prominent papillary architecture. According to the WHO Classification of Genitourinary tumors, "focal" papillary areas can be seen in conventional clear cell RCC. A recent molecular study demonstrated that clear cell carcinoma with prominent papillary features showed similarities with the typical cases, with frequent mutation in the VHL gene, followed by PRBM1 and 29 other different mutations in various genes (Alaghehbandan et al. 2019).

Other rather less frequent differential diagnosis would include collision tumors showing a papillary tumor and conventional clear cells, succinate dehydrogenase (SDH)deficient renal cell carcinoma, fumarate hydratasedeficient RCCs, and RCCs with leiomyomatous stroma
(Trpkov and Hes 2019). Eosinophilic Solid and Cystic Renal Cell Carcinoma (ESC RCC) may also show focal papillary and clear cell morphology (Siadat and Trpkov 2020). Recently, a report showed three cases of "metastatic ALK-rearranged papillary RCC", and tumors in this spectrum should also be considered (Pal et al. 2018).

Papillary RCC (PRCC) with clear cells or PRCC with cytoplasmic clearing is uncommon but is a well-known morphologic variation that enters the differential diagnosis of RCCs with both papillary growth and clear cells. This diagnosis should be entertained in the following scenarios: an RCC with clear cells but extensive papillary growth (conspicuous papillary architecture is not a feature of conventional clear cell RCC); high nuclear grade (ISUP 3 or 4) or necrosis (these are not features of clear cell papillary RCC); extensive papillary pattern with clear cells with ancillary tests ruling out TFE3 and TFEB translocations. In such cases, the immunophenotype of positivity for pan-cytokeratin, cytokeratin 7 and alphamethyacyl coenzyme A racemase (AMACR) is supportive of papillary RCC (Tickoo et al. 2015). Most often, however, the diagnosis of PRCC with clear cell changes is straightforward since clear cells are a minor component of a tumor with otherwise typical type 1 morphology. Further characterization of papillary renal cell carcinoma is provided below.

Table 2 reviews key recommendations for papillary tumors with predominant clear cells.

\section{Papillary tumors and their main differential diagnoses} Papillary renal cell carcinoma (PRCC) is a heterogeneous disease that has traditionally been subdivided into two types (Moch et al. 2016). Subtyping PRCC is controversial and no longer required. Type 1 PRCC is characterized by papillae lined by a single layer of cells with scant pale cytoplasm and low nucleolar grade (Fig. 3a). Strong and diffuse staining for CK7 and AMACR are typical and useful for challenging cases. These tumors commonly share cytogenetic alterations such as gains of chromosomes 7 and 17 and loss of Y chromosome. Frequently $M E T$ gene mutation is also observed. Rarely, germline $M E T$ mutation is seen in the setting of hereditary PRCC, characterized by multiple and bilateral RCC. PRCC with this morphology is further discussed below in light of the differential diagnosis of renal cell tumors with predominant basophilic cells.

Type 2 PRCC is a heterogenous group of tumors. They are characterized by nuclear pseudostratification with cells containing voluminous eosinophilic cytoplasm and usually high nucleolar grade (Fig. 3b). Recent molecular studies suggest that these tumors show a wide spectrum of genetic changes and may not constitute a single entity (Cancer Genome Atlas Research Network et al. 2016). A worse clinical behavior is attributed to type 2 
Table 2 Papillary tumors with predominant clear cells

\begin{tabular}{|c|c|c|c|}
\hline & Typical histology & Expected immunoprofile & Recommendation \\
\hline Clear cell papillary & $\begin{array}{l}\text { Papillary or tubular growth, nuclei arranged } \\
\text { away from basement membrane (reverse polarity), } \\
\text { low grade nuclei, no necrosis }\end{array}$ & $\begin{array}{l}\text { CK7+ } \\
\text { CAIX+ } \\
\text { GATA3+ }\end{array}$ & $\begin{array}{l}\text { - No IHC needed if typical morphology } \\
\text { - Perform IHC panel when other entities } \\
\text { are in the differential }\end{array}$ \\
\hline Xp11 translocation & $\begin{array}{l}\text { Large epitheloid clear and eosinophilic cells, } \\
\text { psammoma bodies }\end{array}$ & $\begin{array}{l}\text { TFE3+, } \\
\text { Cathepsin K+ }\end{array}$ & $\begin{array}{l}\text { - refer to TFE3 break-apart FISH testing } \\
\text { (if TFE3 immunostain not available) if } \\
\text { suggestive morphology or presentation } \\
<50 \text { year or with lymph node metastasis }\end{array}$ \\
\hline $\begin{array}{l}\text { Papillary (with } \\
\text { clear cells) }\end{array}$ & $\begin{array}{l}\text { extensive papillary growth, high nuclear grade } \\
\text { (ISUP } 3 \text { or 4) or necrosis }\end{array}$ & $\begin{array}{l}\text { Pan-cytokeratin + } \\
\text { CK7 + } \\
\text { AMARC + } \\
\text { TFE3/TFEB - }\end{array}$ & - rule out MiT family traslocation \\
\hline
\end{tabular}

morphology. Papillary morphology is shared with other RCC types that must be ruled, especially FH-deficient RCC (see Table 3). Type 2 PRCCs usually show variable positivity and pattern of CK7 and AMACR expression.

Oncocytic PRCC/Papillary Renal Cell Neoplasm with Reverse Polarity is a third variant of PRCC with thin branching papillary architecture, delicate fibrovascular cores covered by a single layer of cuboidal oncocytic cells low grade nuclei aligned at the apical surface. Tumors with this morphology are not yet fully characterized. They are negative for vimentin and c-KIT. These tumors have consistent positivity for GATA3 and frequent KRAS mutations, suggesting that it may be an emerging entity (Al-Obaidy et al. 2019; Kim et al. 2020).

Mucinous tubular and spindle cell carcinoma (MTSCC) is a rare, polymorphic carcinoma, consisting of a tightly packed tubular component lined by cuboidal cells that transitions into a bland spindle cell component, set in a variable amount of mucinous / myxoid stroma (Fig. 3c). For the most part, these tumors show low-grade cytology and indolent behavior, although rare tumors with high-grade nuclei and sarcomatoid change have been reported (Bulimbasic et al. 2009; Kuroda et al. 2008). Although the typical triad of low-grade tubules,

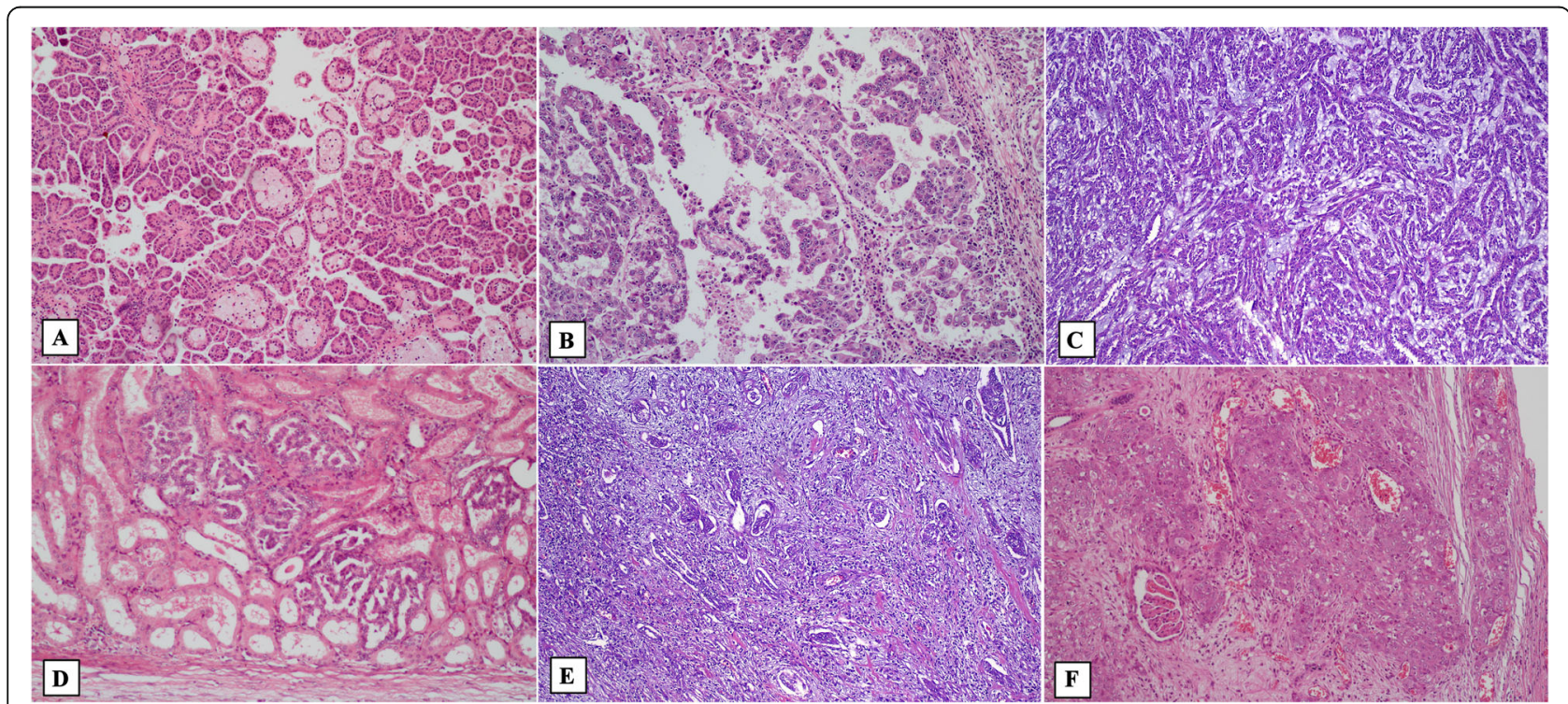

Fig. 3 Renal cell carcinomas with papillary features and some of their differential diagnoses. Type 1 Papillary RCC exhibits papillae lined by a single layer of cells with scant pale cytoplasm and low nucleolar grade. Foamy macrophages within fibrovasculares cores are a common finding (a HE, 100x). Type 2 Papillary RCC displays nuclear pseudostratification with cells containing voluminous eosinophilic cytoplasm and generally high nucleolar grade. In this case, such nucleolar prominence imposes further evaluation to exclude fumarate hydratase deficiency (b HE, 100x). Mucinous tubular and spindle cell carcinoma consists of tightly packed tubular component lined by cuboidal cells that transitions into a bland spindle cell component, set in a variable amount of mucinous / myxoid stroma (c HE, 100x). Papillary adenoma shows identical architectural and cytologic features to classic type 1 PRCC but the diagnosis required low nuclear grade, absent fibrous capsule and size $\leq 15 \mathrm{~mm}$ (d HE, 100x). Collecting duct carcinoma consists in a high-grade adenocarcinoma that usually show tubular morphology, and highly infiltrative growth with associated desmoplastic reaction (e HE, 40x). Medullary carcinoma - solid areas of highly infiltrative high-grade carcinoma inducing desmoplastic reaction in renal cortex - note preexistent tubules and glomerulus intermixed with the infiltrative tumor. This was an advanced stage RCC diagnosed in a 25-year-old female patient with sickle cell anemia (f HE, 100x) 
Table 3 Papillary tumors, with predominant eosinophilic cells

\begin{tabular}{|c|c|c|c|}
\hline & Typical histology & Expected immunoprofile & Recommendation \\
\hline Papillary & $\begin{array}{l}\text { Nuclear pseudostratification, voluminous } \\
\text { eosinophilic cytoplasm, high nucleolar grade }\end{array}$ & CK7 and AMARC variable & - rule out FH deficient \\
\hline $\begin{array}{l}\text { Fumarate hydratase } \\
\text { deficient }\end{array}$ & $\begin{array}{l}\text { Prominent cherry-like nucleoli (may be focal); } \\
\text { Mixed patterns including tubulocystic, papillary } \\
\text { intracystic, tubulopapillary. }\end{array}$ & $\begin{array}{l}\text { 2SC overexpression, } \\
\text { FH negative }\end{array}$ & $\begin{array}{l}\text { - recommend genetic testing for } \mathrm{FH} \\
\text { mutations (if } 2 \mathrm{SC} / \mathrm{FH} \text { immunostain } \\
\text { not available) in eosinophilic unclassified, } \\
\text { papillary type } 2 \text {, collecting duct carcinoma } \\
\text { and tubulopapillary with solid foci }\end{array}$ \\
\hline Xp11 translocation & $\begin{array}{l}\text { Large epitheloid clear and eosinophilic cells, } \\
\text { psammoma bodies }\end{array}$ & $\begin{array}{l}\text { TFE3+, } \\
\text { Cathepsin } \mathrm{K}+\end{array}$ & $\begin{array}{l}\text { - refer to TFE3 break-apart FISH testing } \\
\text { (if TFE3 immunostain not available) if } \\
\text { suggestive morphology or presentation } \\
<50 \text { year or with lymph node metastasis }\end{array}$ \\
\hline Collecting duct & Infiltrative growth, desmoplastic stromal reaction & $\begin{array}{l}\text { PAX8+ } \\
\text { CK7 + } \\
\text { SMARCB1/INI-1 + } \\
\text { HMWCK + } \\
\text { OCT3/4 - } \\
\text { GATA3 - } \\
\text { P63 - }\end{array}$ & $\begin{array}{l}\text { - diagnosis of exclusion after ruling out FH } \\
\text { deficient, medullary, urothelial and metastatic } \\
\text { carcinoma }\end{array}$ \\
\hline Medullary & $\begin{array}{l}\text { Infiltrative growth; desmoplastic stromal reaction; } \\
\text { adenoid cystic, reticular and microcystic patterns }\end{array}$ & $\begin{array}{l}\text { PAX8+ } \\
\text { CK7 + } \\
\text { SMARCB1/INI-1- } \\
\text { HMWCK - } \\
\text { OCT3/4 + }\end{array}$ & $\begin{array}{l}\text { - only diagnose it if proved sickle cell disease } \\
\text { or sickle cell trait }\end{array}$ \\
\hline
\end{tabular}

spindle cell component and mucin are classic findings, these tumors tend to be more heterogeneous than originally described, some being mucin-poor, tubularpredominant, spindle cell-predominant, or having focal unusual features that make a definitive diagnosis challenging (foamy macrophages, focal papilla, focal clear cells, focal oncocytic change) (Fine et al. 2006). The main differential diagnostic consideration for MTSCC is PRCC that has predominantly solid or tubular architectural patterns or contains low-grade spindle cell areas (Renshaw et al. 1997; Argani et al. 2008; Ren et al. 2018). In addition to their overlapping morphology, MTSCC and PRCC also share a common immunoprofile, both being CK7 and AMACR positive. Recently, a study by Ren et al. has shown that they are in fact distinct entities and harbor different molecular alterations. MTSCC shows multiple chromosomal losses, most frequently involving chromosomes 1, 4, 6, 8, 9, 13, 14, 15, and 22, while lacking trisomy 7 or 17 , the latter being one of the molecular hallmarks of PRCC (Ren et al. 2018). Since evaluation of copy number alterations is not always readily available in our setting, three morphologic features are the most helpful in differentiating these two entities: 1) Presence of a distinct area of well-formed type 1 papillae; 2) Spindled tumor cells lining angulated, curvilinear tubules with irregular and "shaggy" lumina, as opposed to smooth inner contours; 3) Micronodules encompassing small branching papillae that clearly contain fibrovascular cores (Ren et al. 2018). These three features were only observed in PRCC cases in the Ren et al. series.
Fumarate hydratase (FH) deficient $\mathbf{R C C}$ is a rare entity characterized by $F H$ gene mutation. Due to its strong association with Hereditary Leiomyomatosis and Renal Cell Carcinoma (HLRCC) syndrome, this tumor is named HLRCC-RCC in the current WHO classification (Moch et al. 2016). Patients with HLRCC have a germline $F H$ mutation and frequent association with cutaneous or uterine leiomyomas. The term "FH-deficient" however comprises the hereditary and sporadic forms of the tumor that share common morphologic features and aggressive biological behavior. These tumors were originally described as showing papillary architecture, similar to type 2 PRCC with prominent inclusion-like nucleoli. However, recent studies have shown a wide morphological spectrum, including solid sheets, cords, nests, infiltrating glands, intracystic papillary, tubulocystic with poorly differentiated foci (Smith et al. 2016) and tubulopapillary patterns, frequently having mixed patterns (Ohe et al. 2018). Thus, one should rule out FHdeficient RCC before calling unclassified RCC, collecting duct carcinoma or tubulocystic carcinoma.

In a study based on screening with $\mathrm{FH}$ immunohistochemistry, FH-deficient tumors were identified among renal cell carcinomas originally diagnosed as papillary $(2 / 400$, or $0.5 \%)$ or unclassified (2/46, or $4,4 \%)$ (Gupta et al. 2019). Among 33 young ( $\leq 35$ years) patients with unclassified RCCs with predominance of eosinophilic cells, 4 (12\%) proved to be FH-deficient (Li et al. 2018).

Whenever feasible, FH immunohistochemistry is a valuable way to screen tumors with $F H$ mutations (Fig. 4). However, FH positive immunohistochemistry 


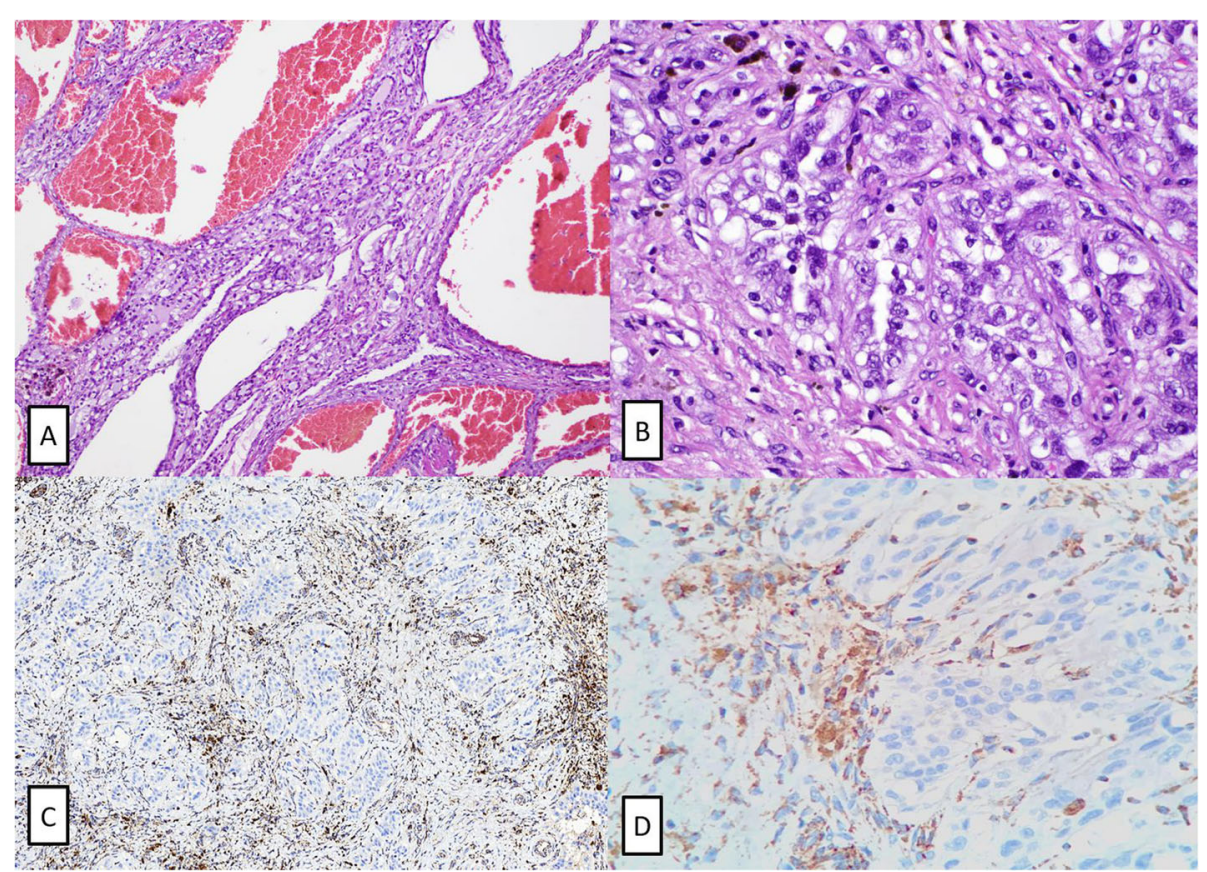

Fig. 4 Fumarate hydratase - deficient renal cell carcinoma. Tubulocystic growth intermixed with a solid component (a HE, 100x). Higher magnification shows prominent nucleoli (b HE, 400x). Fumarate hydrase immunostain show loss of cytoplasmatic staining in tumor cells while expression is retaining in adjacent stromal cells (c and $\mathbf{d} 40 \mathrm{x}$ and 400x)

occurs in 10 to $20 \%$ of FH deficient RCC (Williamson et al. 2020). If not available, pathologist should have a low threshold to suggest the genetic testing for germline FH mutation in patients with unclassified eosinophilic, papillary or with mixed morphologies RCCs. Detection of FH deficient RCCs is important because it identifies tumors with aggressive behavior and with potential association with a hereditary syndrome.

Xp11 translocation RCC. MiT family translocation RCC harbor gene fusions involving two transcription factors: TFE3 - associated with Xp11 translocations and TFEB - associated with $\mathrm{t}(6 ; 11)$ translocation. The most characteristic feature of Xp11 translocation $\mathrm{RCC}$ is the presence of papillae lined by epithelioid clear and eosinophilic cells with abundant psammoma bodies. Thus, this tumor should be considered in the differential diagnosis of clear cell neoplasms (Fig. 1e, Table 2). On the other hand, this tumor may show a mixture of morphologies that may be indistinguishable of conventional clear cell RCC, multilocular cystic neoplasm of low malignant potential, oncocytoma and epithelioid angiomyolipoma (Caliò et al. 2019; Argani et al. 2007; Green et al. 2013). These tumors usually show no expression or focal positivity for epithelial markers, negative or minimal staining for carbonic anhydrase IX and a small percentage express melanocytic markers, which is more frequently seen in the TFEB - associated with $t(6 ; 11)$ translocation tumors. They commonly express cathepsin
$\mathrm{K}$ and the distinction from epithelioid angiomyolipoma may rely on the expression of PAX8 in the Xp11 translocation RCC (Tickoo et al. 2015). The presence of translocation can be evaluated by TFE3 immunohistochemistry or by TFE3 break-apart FISH assay.

These tumors disproportionally affect children and commonly present with local lymph node metastasis which does not seem to impact prognosis. The overall prognosis seems to be comparable with clear cell RCC. Immunohistochemistry for TFE3 protein can be helpful. In addition, melanocytic markers and cathepsin $\mathrm{K}$ can be performed. Evaluation of TFE3 translocations should be considered in clear cell or eosinophilic cell predominant RCCs when presenting at younger age ( $<50$ years), with a combination of growth patterns, presence of regional lymph node metastasis and suggestive morphology (clear cell papillary with psammoma bodies and high grade features). Use of immunohistochemistry for melanocytic markers or cathepsin $\mathrm{K}$ in clear cell or eosinophilic RCCs with typical features of other subtypes is not recommended. The International Society of Urologic Pathology also recommends testing of TFE3 translocations in RCCs diagnosed in patients younger than 30 years (Tan et al. 2013).

$\mathrm{T}(6 ; 11)$ translocation $\mathrm{RCC}$ is much rarer. The most distinctive pattern is of a biphasic tumor with large epithelioid cells in the periphery and smaller cell in the center of large nests, commonly clustering around 
basement membrane deposits (Fig. 1f). The morphologic spectrum may show also papillary and tubulocystic patterns, clear cell, and oncocytoma-like features (Caliò et al. 2019). These tumors usually show no expression or focal positivity for epithelial markers, about half of them express melanocytic markers and cathepsin $\mathrm{K}$ and, as it does for Xp11 translocation RCC, the distinction from epithelioid angiomyolipoma may rely on the expression of PAX8 in the $\mathrm{t}(6 ; 11)$ translocation RCC (Tickoo et al. 2015). About $50 \%$ of $t(6 ; 11)$ translocation RCCs do not express PAX8 (Kryvenko et al. 2014) but a recent report suggest a positivity rate of $88 \%$ (Caliò et al. 2020). The presence of translocation can be evaluated by TFEB immunohistochemistry or by TFEB break-apart FISH assay. It most commonly follows an indolent course, with few reports of metastatic behavior. Evaluation of TFEB translocation should be performed in tumors with suggestive morphology and, since immunohistochemical features may be indistinguishable, it should be considered in otherwise purely epithelioid angiomyolipomas lacking expression of epithelial markers and PAX8. The International Society of Urologic Pathology also recommend testing of TFEB translocations in RCCs diagnosed in patients younger than 30 years (Tan et al. 2013). Based on lack of availability of TFEB immunohistochemistry or FISH tests in our setting, immunohistochemical features such as absence of cytokeratin expression and positivity for cathepsin $\mathrm{K}$ and melanocytic markers may be used as evidence for strongly suggestive of $\mathrm{T}(6 ; 11)$ translocation RCC.

In recent ISUP consultation conference, the morphologic clues that indicates further testing for MiT family translocation-associated RCC (both TFE3 and TFEB) should be mixture of clear and eosinophilic cells, mixture of papillary and nested architecture, psammoma bodies, hyalinized stroma, unusual voluminous cytoplasm and pigment deposition (Williamson et al. 2020). Some cases of rearrangements of TFE3 and TFEB genes are not detectable by FISH break apart assays and may require gene sequencing.

Collecting duct carcinoma (CDC) accounts for 1-2\% RCC and consists in a high-grade adenocarcinoma. Diagnostic criteria are medullary involvement, predominant tubular morphology (even though tubulopapillary and papillary patterns are common), desmoplastic stromal reaction, high-grade nuclei and absence of other RCC subtypes or urothelial carcinoma (Moch et al. 2016) (Fig. 3e). It consistently expresses high-molecular weight cytokeratin and cytokeratin 7 . The differential diagnosis with medullary RCC, FH deficient RCC and urothelial carcinoma can be challenging due to overlapping morphology and immunoprofile. When dealing with a possible $\mathrm{CDC}$, it is recommended to test expression of PAX8 as tool to reinforce kidney as primary site and exclude metastatic adenocarcinoma if PAX8 is negative (Moch et al. 2016). A useful panel for the differential diagnosis set above should include SMARCB1/INI-1 (typically lost in medullary and in about $15 \%$ of collecting duct RCC), cytokeratin 34ßE12 (usually negative in medullary), GATA3 and p63 (positive in urothelial carcinoma), OCT4 (expressed in medullary carcinoma) and $\mathrm{FH}$ (lost in $\mathrm{FH}$ deficient RCC). PAX8 is expressed in CDC and medullary RCC and may be positive in urothelial carcinoma of the upper urinary tract (20\%) (Reuter et al. 2014).

In the recent ISUP consultation conference, CDC is considered a diagnosis of exclusion requiring investigation of FH deficiency, medullary carcinoma (sickle cell disease and/or sickle cell trait, and loss of SMARCB1/ INI-1 expression) and urothelial differentiation (Williamson et al. 2020).

Medullary carcinoma is an overly aggressive RCC centered in renal medulla which is associated with sickle cell trait or disease, or related hemoglobinopathies. The morphology is similar to CDC showing tubular, papillary and infiltrative architectures (Fig. 3f). Most distinctive findings for medullary RCC are adenoid cystic, reticular and microcystic patterns. Some tumors show pure forms of solid and sheet-like growth, or rhabdoid morphology. Altered erythrocytes (crescent-shaped, holly-leaf -/scythe-like cells caused by polymerization or sickling of hemoglobin $\mathrm{HbS}$ ) called sickle cells (drepanocytes) are commonly seen in small vessels. Tumor morphology and the presence of sickle cells in tumor microvasculature or clinical diagnosis of sickle cell trait or disease may suggest the diagnosis of medullary carcinoma (Moch et al. 2016). RCCs with typical features of medullary carcinoma require proven sickle cell trait or disease by hemoglobin electrophoresis. If such conditions are ruled out, a diagnosis of unclassified RCC with renal medullary phenotype is recommended (Sirohi et al. 2017).

Key recommendations on the differential diagnosis of tumors with papillary morphology are provided in $\mathrm{Ta}$ bles 2 (predominantly clear cells), 3 (predominantly eosinophilic cells) and 4 (predominantly basophilic cells).

\section{Oncocytic tumors}

There are two important points to keep in mind when evaluating a solid non-papillary kidney tumor with predominant eosinophilic cells. First, the most commonly resected benign epithelial neoplasm of the kidney is oncocytoma, which may fit this description. Despite having a broad morphologic spectrum, some features exclude the diagnosis of oncocytoma, such as papillary growth, clear cells outside areas of fibrous scar and necrosis. Secondly, clear cell carcinoma is the most common malignant epithelial neoplasm of the kidney. Although it is named "clear cell", a common feature of 
Table 4 Tumors with basophilic cells

\begin{tabular}{|c|c|c|c|}
\hline & Typical histology & $\begin{array}{l}\text { Expected } \\
\text { immunoprofile }\end{array}$ & Recommendation \\
\hline Papillary carcinoma & $\begin{array}{l}\text { Papillary architecture, but tubulopapillary, glomeruloid, } \\
\text { and dense papillary simulating solid; single layer of cuboidal } \\
\text { cells; foamy macrophages and psammoma bodies }\end{array}$ & $\begin{array}{l}\text { CK7+ } \\
\text { AMARC+ }\end{array}$ & $\begin{array}{l}\text { - no IHC needed if typical morphology } \\
\text { - consider differential with papillary } \\
\text { adenoma and metanephric adenoma }\end{array}$ \\
\hline Papillary adenoma & $\begin{array}{l}\text { Similar to papillary RCC type } 1 \text {; low grade nuclei, no } \\
\text { fibrous capsule, } \leq 15 \mathrm{~mm}\end{array}$ & $\begin{array}{l}\text { CK7+ } \\
\text { AMARC+ }\end{array}$ & - no IHC needed if typical morphology \\
\hline $\begin{array}{l}\text { Mucinous tubular and } \\
\text { spindle cell carcinoma }\end{array}$ & $\begin{array}{l}\text { Small tubules lined by cuboidal cells, bland spindle cell } \\
\text { component, variable amount of mucinous / myxoid stroma }\end{array}$ & $\begin{array}{l}\text { CK7+ } \\
\text { AMARC+ }\end{array}$ & - no IHC needed if typical morphology \\
\hline Metanephric adenoma & $\begin{array}{l}\text { Small tubules that may simulate solid areas; glomeruloid } \\
\text { and/or papillary formations }\end{array}$ & $\begin{array}{l}\text { WT1 + } \\
\text { CD56 + } \\
\text { BRAF VE1 + } \\
\text { CK7- } \\
\text { AMARC - }\end{array}$ & - rule out papillary carcinoma \\
\hline
\end{tabular}

this tumor is the eosinophilic change in the cytoplasm of tumor cells, mainly in higher-grade areas.

Oncocytoma comprises $4-7 \%$ of all kidney tumors resected in adults with peak incidence between 50 and 80 years. It is the prototype of neoplasm composed of cells with abundant eosinophilic (oncocytic) cytoplasm that may grow in nests, alveoli and tubules. Typically, these tumors are grossly brown with a central fibrous or myxoid scar. Islands of eosinophilic cells within fibrous stroma are characteristic (Fig. 5a). Cytologically, oncocytomas are characterized by round nuclei with regular contours, and small visible nucleoli. Binucleation is common. Clusters of small cells with scant cytoplasm may be seen (so-called oncoblasts) as well as degenerative atypia (bizarre, pleomorphic cells with smudgy chromatin, but lacking mitotic activity). Exclusion criteria for the diagnosis of oncocytoma are papillary growth, clear cells outside areas of fibrous scar, and necrosis. Attention to true papillary formation is important because it should prompt consideration of malignant tumors. Focal epithelial protrusions (papillary-like formations) within dilated tubules / microcysts are allowed, as well as extension to perinephric adipose tissue and into vessels (Trpkov et al. 2010).

Oncocytomas are benign. Therefore, distinction from any other malignant tumors, particularly the eosinophilic variant of chromophobe renal cell carcinoma which shows the most morphologic overlap, is crucial due to psychosocial and management implications of a benign versus malignant diagnosis. When considering a differential diagnosis with chromophobe carcinoma, a diffuse positive reaction for cytokeratin 7 (CK7) favors chromophobe carcinoma. Complete absence of CK7 or predominant negative neoplasm with isolated cells or small clusters of tumor cells staining favors oncocytoma. Both tumors are immunoreactive for c-KIT (CD117) and this finding may help narrow the differential diagnosis. Use of genetic testing or cytogenetic studies for the distinction between oncocytoma and chromophobe carcinoma is not needed, morphology being the mainstay of diagnosis.

Chromophobe renal cell carcinoma comprises 5-7\% of renal cell carcinomas. The typical morphology includes large eosinophilic cells (oncocytoma-like) and vegetal-like cells (with distinct cytoplasmic membrane). Cytoplasm may be eosinophilic or finely granular with perinuclear halos and nuclei showing "raisinoid"/ shrunken morphology (Fig. 1b). The nuclear atypia in chromophobe RCC does not predict prognosis and, as a consequence, nuclear grade does not apply and should not be provided in chromophobe RCCs (Delahunt et al. 2013). The typical architecture is solid with extension to adjacent renal parenchymal entrapping preexistent tubules. Nests, broad alveoli and trabeculae may be seen. The tumor may show many chromosomal losses although testing them are usually not required for the diagnosis. With appropriate morphology, the immunophenotype of diffuse CK7 staining and diffuse membranous c-KIT staining is supportive of the diagnosis of chromophobe carcinoma (Reuter et al. 2014).

Some patients have hybrid oncocytic tumors with features of oncocytoma and chromophobe RCC. Although the Birt-Hogg-Dubé-associated kidney cancer pathologic phenotype can be variable (chromophobe RCC and some oncocytic tumors with clusters of clear cells) (Zhou and Magi-Galluzi 2015), nearly 60\% of tumors are hybrid/ oncocytic renal cell carcinoma. It is recommended to test germline FLCN mutation, beginning at age 21, in families of patients with cutaneous fibrofolliculomas, familial pulmonary cysts/pneumothorax and/or those found to have a hybrid/oncocytic renal tumors (Linehan 2013). Other hybrid tumors are associated with oncocytomatosis or sporadics forms (Srigley et al. 2013; Williamson et al. 2020). By the consensus classification of kidney tumors by ISUP, these hybrid tumors are named hybrid oncocytic/chromophobe tumors and considered a subcategory of chromophobe renal cell carcinoma (Srigley et al. 2013). 


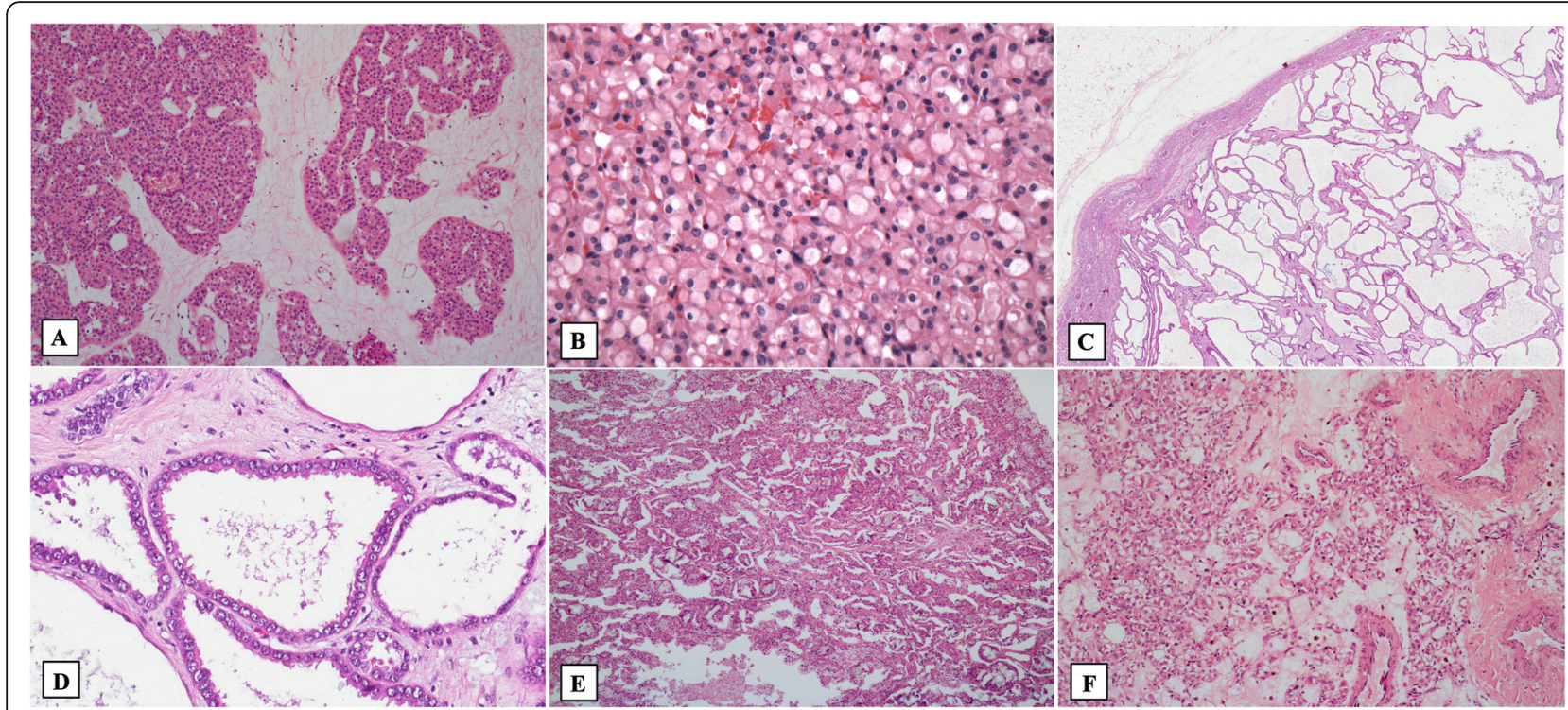

Fig. 5 Oncocytic renal tumors and some of their differential diagnoses. Oncocytoma - typical area of insular growth of oncocytic cells in a loose fibrous stroma (a HE, 100x). Succinate dehydrogenase (SDH) deficient renal cell carcinoma shows diffuse solid growth of eosinophilic cells with and vacuolated cytoplasm or granular flocculent appearance (b HE, 200x; courtesy of Dr. Kiril Trpkov, University of Calgary). Tubulocystic carcinoma is formed by small and medium sized tubules with occasional cystic dilated tubules. The tumor cells have eosinophilic/oncocytic cytoplasm and nuclei show a typical prominent nucleolus (HE: c 10x and $\mathbf{d} 100 \mathrm{x}$ ). Acquired cystic disease associated renal cell carcinoma typically displays sieve-like morphology and microcystic architecture with oxalate crystals (e HE, 100x). Epithelioid angiomyolipoma may mimic epithelial tumors with clear and eosinophilic cells ( $f \mathrm{HE}, 100 \mathrm{x}$ )

Chromophobe RCC have better prognosis than clear cell and papillary RCCs, but it is more accurately predicted by pathological stage. Rhabdoid/sarcomatoid and tumor necrosis are factors associated with more aggressive behavior.

Succinate dehydrogenase (SDH) deficient renal cell carcinoma is usually an indolent tumor with morphology that may be reminiscent of chromophobe RCC. It also shows diffuse solid growth, entrapped preexistent tubules, and foci of tubular and nested growth. The most characteristic finding is a vacuolated cytoplasm or granular flocculent appearance (Gill et al. 2011) (Fig. 5b). It is usually of low-grade morphology. About $11 \%$ of patients develop metastasis during follow up and it may be predicted by high-grade and presence of sarcomatoid/rhabdoid morphology.

Succinate dehydrogenase (SDH) deficiency is associated with SDH deficient kidney cancer, gastrointestinal stromal tumors (GIST) and pheochromocytomas/paragangliomas. Mutations of SDHB, SDHC, and SDHD genes (which encodes parts of the mitochondrial complex 2-a respiratory enzyme that links the Krebs cycle and electron transport chain) may be screened by cytoplasmic SDHB protein loss using immunohistochemistry. This evaluation is recommended for all paragangliomas, GISTs and renal cell carcinomas with suggestive morphology (Gill 2012). In a large series of 1009 kidney tumors screened for SDHB immunohistochemistry, only tumors originally diagnosed as oncocytomas were proven to be SDH-deficient renal cell carcinomas: 3/273 (1,1\%) (Gupta et al. 2019). For paragangliomas, $90 \%$ of patients with SDHB loss by immunohistochemistry do harbor some germline SDH gene mutation. Since the SDHB is not widely available in pathology laboratories, an alternative is the direct testing for germline mutation analysis. In addition, it is known that somatic inactivation of SDH genes may (rarely) occur in renal cell carcinoma (Trpkov and Siadat 2019). SDH germline mutation testing is recommended for patients with familial pheochromocytoma and renal cell carcinoma, as well as those with the characteristic SDHB-deficient pathologic pattern (Linehan 2013) or oncocytic kidney tumors with coexistent or past history of GIST or pheochromocytomas/paragangliomas.

It is estimated that $24 \%$ of unclassified RCCs with predominantly eosinophilic cytoplasm or "oncocytomas" diagnosed in patients aged $\leq 35$ years will show loss of SDHB at immunohistochemistry and would be reclassified as SDH-deficient RCC (Li et al. 2018). Ancillary immunohistochemistry for SDHB, FH and cytokeratin 20 (see below) should be considered in cases of oncocytomas in young patients or in eosinophilic cell predominant RCCs that are under consideration for unclassified RCC.

Diagnosis may also be suspected upon an oncocytic tumor that exibits loss of broad-spectrum epithelial markers. Staining for AE1/AE3, CAM5.2, CK7 and EMA 
can be negative or only focally positive, albeit with considerable variations (Williamson et al. 2015). Meanwhile, labeling is usually uniformly positive for PAX8 and kidney-specific cadherin and absent for Oncocytoma/ Chromophobe and Clear cell RCC typical markers, such as KIT, RCC, and carbonic anhydrase IX. Therefore, upon unavailability of B immune-histochemistry, a large IHC panel may direct the diagnosis even further upon the morphologic suspicion.

Table 5 reviews key recommendations on the differential diagnosis of these tumors.

\section{Other types with predominant eosinophilic cells}

Tubulocystic carcinoma is a rare subtype $(<1 \%)$ of renal cell carcinoma. The gross appearance is typically of multicystic mass. At microscopy, the tumor is formed by small and medium sized tubules with occasional cystic dilated tubules. The tumor cells have eosinophilic/oncocytic cytoplasm and nuclei show a typical prominent nucleolus (ISUP grade 3) (Fig. 5c and d). Recognition of this tumor is of relevance to acknowledge that, even though the nuclear grade is high, the expected clinical behavior is of an indolent neoplasm. This tumor is typically positive for cytokeratin 7 and AMARC, however, the diagnosis is mostly based on morphology and immunohistochemistry is usually not required. However, attention should be given to grossing, with wide sampling, since Tubulocystic carcinomas with poorly differentiated areas have been associated with FH-deficiency and shown to behave aggressively (Smith et al. 2016; Williamson et al. 2020). Therefore, poorly differentiated adenocarcinoma areas should be reported and immunohistochemistry with FH and 2SC, along with clinical investigation, are recommended in this scenario (see Fig. 4). Poorly differentiated foci exclude the diagnosis of tubulocystic carcinoma, and the evaluation of FH deficiency will allow documentation of FH-deficient RCC.

Acquired cystic kidney disease (ACKD) associated renal cell carcinoma is a specific subtype occurring in end-stage kidney disease. Renal cell carcinomas occur in $3-7 \%$ of patients with acquired cystic disease, and those patients are under a risk of developing renal carcinomas that is 100x higher than the general population. Many of the tumors that arise in end-stage kidney disease are clear cell papillary, clear cell and papillary RCCs. About half of tumors in this context has distinct morphologic features deserving the diagnosis of specifically associated with acquired cystic disease. They are grossly solid, multifocal in half of all cases and bilateral in $20 \%$. At microscopy, they show a mixture of acinar, alveolar, tubular, papillary, solid and multicystic patterns. The most characteristic areas show sieve-like and microcystic architecture with oxalate crystals (Fig. 5e) (Tickoo et al. 2006; Bhatnagar and Alexiev 2012). Genomic studies show gains in chromosomes 3,6,7 and Y. They usually follow an indolent course, but may show aggressive behavior in the presence of sarcomatoid/rhabdoid morphology. Based on morphology and clinical setting, immunohistochemistry and molecular studies are not required for this diagnosis.

Table 5 reviews key recommendations on the differential diagnosis of these tumors.

\section{Tumors with predominant basophilic cells}

Papillary RCC is the second most common type of RCC, accounting for 15-20\% of RCCs (Amin et al. 2002). Tumors within the type 1 morphologic spectrum are characterized by papillary architecture, but tubulopapillary, glomeruloid, and dense papillary simulating solid areas may be encountered. The papillae are slender and lined by a single layer of cuboidal cells with scant, basophilic cytoplasm and inconspicuous nucleoli. Foamy macrophages and psammoma bodies are often present in the papillary cores. These tumors are bound by a pseudocapsule and are typically low grade. However, cases with high-grade nuclear features (prominent nucleoli, non-basophilic cytoplasm), sometimes accompanied by invasive growth, may occur. (Chevarie-Davis et al. 2014) These high-grade areas are usually limited but may be a significant component of an otherwise classic (morphologically and immunohistochemically type 1 PRCC). Such tumors should be categorized as highgrade PRCC, however, limited evidence suggests these behave in an indolent fashion (Chevarie-Davis et al. 2014; Murugan et al. 2014). PRCC with basophilic cells is diffusely and strongly positive for CK7, AMACR (P504S), and CD10. The tips of papillae often show CAIX positivity, a possible pitfall depending on the differentials being considered, however, it is never diffusely positive. Molecularly, these PRCCs are characterized by frequent MET pathway alterations and multiple chromosomal gains (particularly of chromosomes 7 and 17, and less frequently of chromosomes 2, 3, 12, 16, and 20) and frequent loss of chromosome Y (Cancer Genome Atlas Research Network et al. 2016). The differential diagnosis mainly includes papillary adenoma, metanephric adenoma, and mucinous tubular and spindle cell carcinoma (Table 4). Multiple and/or bilateral PRCC should prompt consideration of hereditary PRCC syndrome.

Papillary adenoma shows identical architectural and cytologic features to classic type 1 PRCC (therefore, low nuclear grade), but, by definition, lacks a fibrous capsule and measures $\leq 15 \mathrm{~mm}$. These tumors are often incidental findings in autopsy or nephrectomy specimens (Fig. $3 \mathrm{~d})$. The frequency is higher in the setting of chronic renal disease and patients submitted to long-term dialysis (Moch et al. 2016). Multiple papillary adenomas are 


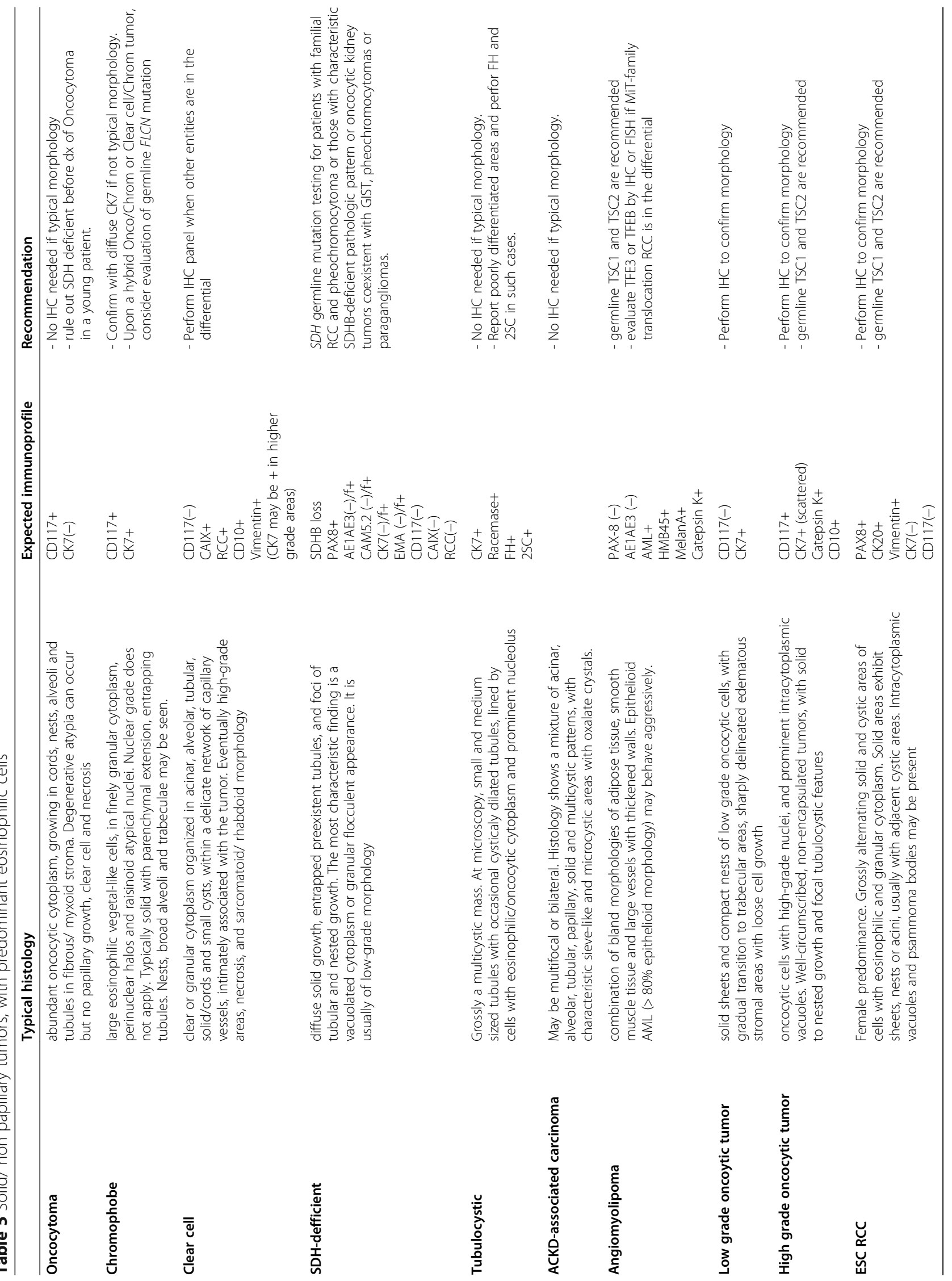


common in kidneys of patients with hereditary papillary renal cancer (Ornstein et al. 2000).

Metanephric adenoma is a highly cellular, benign epithelial neoplasm that may be derived from persistent blastema or may represent an extreme maturation of nephroblastoma. It occurs in all age groups. Typically, it consists of tightly packed acini formed by small, uniform and round cells. Acini may be very small, simulating a solid pattern; about half of cases show glomeruloid and/or papillary formations. Psammoma bodies are common. This entity also includes PRCC as its main mimic. Morphologic clues that favor metanephric adenoma over PRCC are absence of a pseudocapsule and uniform nuclei with inconspicuous nucleoli. Immunohistochemistry, however, makes distinction between the two tumors fairly easy: WT1 and CD57 positive in metanephric adenoma, while negative for CK7. AMACR (P405S) may be positive in both and is therefore not helpful in this scenario. Interestingly, $90 \%$ of metanephric adenomas show BRAF V600E mutations (Moch et al. 2016), making BRAF VE1 a valuable imunohistochemical marker to be used (Udager et al. 2015; Pinto et al. 2015; Ritterhouse and Barletta 2015) (Fig. 6).

Table 4 reviews key recommendations for renal cell tumors with predominant basophilic cells.

\section{Mesenchymal tumors that may be considered in differential diagnosis}

Angiomyolipomas comprise $0.7-2.0 \%$ of all renal tumors and about $20 \%$ of them area associated with tuberous sclerosis (Flum et al. 2016). As a consequence, germline mutations of TSC1 gene and the TSC2 gene are recommended. The pathological diagnosis is usually straightforward due to characteristic combination of bland morphologies of adipose tissue, smooth muscle tissue and large vessels with thickened walls. The clinical behavior is benign in the absence of epithelioid morphology. The diagnosis of epithelioid angiomyolipomas requires more than $80 \%$ of epithelioid cells. Epithelioid angiomyolipoma has metastatic potential may also be associated with tuberous sclerosis. Metastatic behavior is predicted by larger size $(>7 \mathrm{~cm})$, carcinoma-like atypia, involvement of perinephric tissues, renal vein invasion and necrosis. Those aggressive epithelioid angiomyolipoma may mimic high-grade eosinophilic renal cell carcinomas (Fig. 5f).

It is important to keep in mind that, in the scenario of a high-grade eosinophilic epithelioid/epithelial neoplasm of the kidney, the immunophenotype of epithelioid angiomyolipoma and MiT translocation RCC may show considerable overlapping features. Most primary renal carcinomas ( $>95 \%)$ express pan-cytokeratin marker and PAX8 and commonly angiomyolipoma will show obvious areas of smooth muscle differentiation, and corresponding smooth muscle actin expression. On the other hand, epithelioid angiomyolipoma show variable expression of smooth mucle actin and is negative for PAX8 and cytokeratins; while MiT family translocation carcinoma (particularly TFEB, see below) may show in about

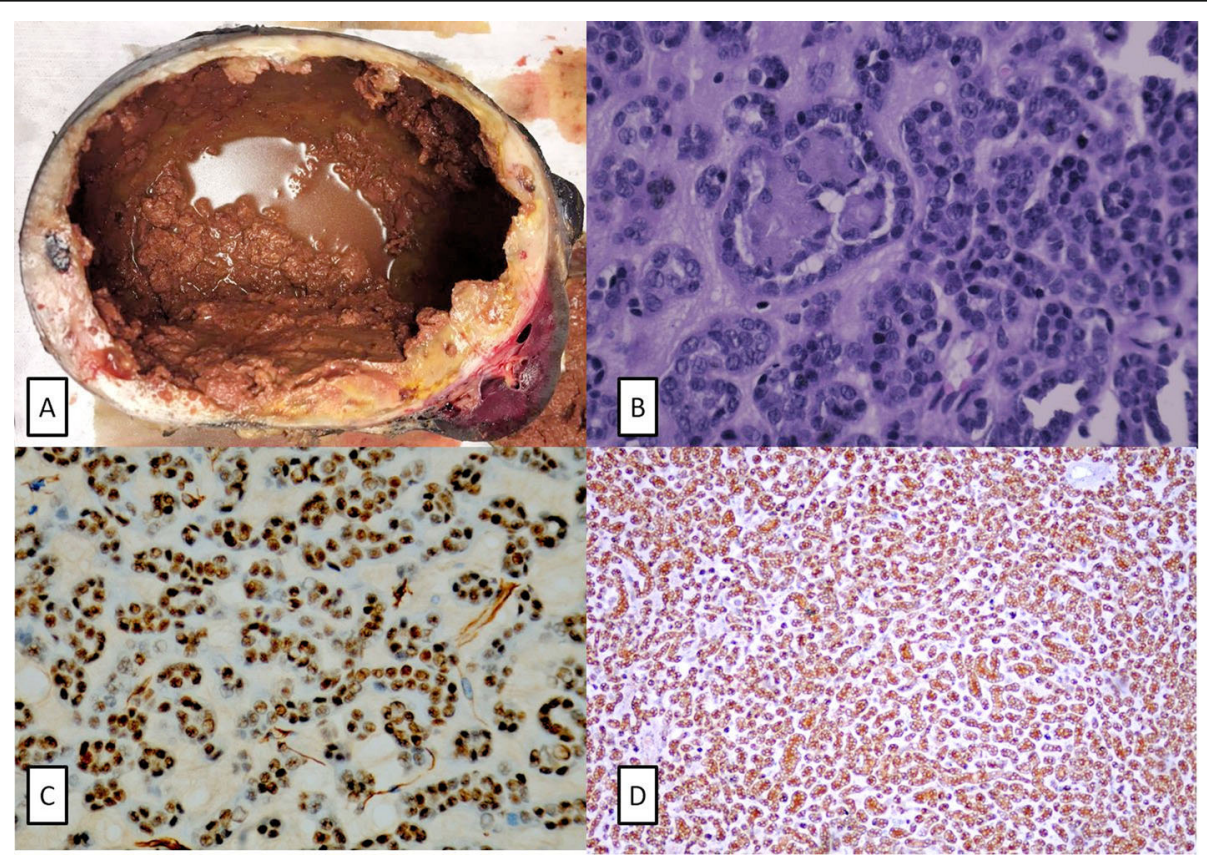

Fig. 6 Metanephric adenoma. The gross appearance was of a predominantly cystic tumor in this particular case (a). Microscopy shows small tubules and glomeruloid structures (b HE, 400x). Characteristic immunoprofile includes diffuse staining for WT1 (c 100x) and BRAF VE1, a surrogate immunohistochemical marker of BRAF V600E mutation (d 40x) 
half of cases no expression of PAX8 and cytokeratins (Kryvenko et al. 2014). Both epithelioid angiomyolipoma and MiT family translocation carcinoma (particularly TFEB, again) commonly express cathepsin $\mathrm{K}$ and melanocytic markers such as MelanA and HMB45 (Kryvenko et al. 2014; Tickoo et al. 2015). For this differential diagnosis, when smooth muscle actin and PAX8 are not helpful, the distinction relies on the evaluation of specific translocations by FISH or, alternatively, by immunohistochemistry using anti-TFE3 and anti-TFEB antibodies which are not widely available (see below). Of notice, however, perivascular epithelioid cell neoplasms (PEComas) may show aberrant expression of TFE3 protein by immunohistochemistry (without translocation) and a subset of them - including renal epithelioid angiomyolipoma - may harbor TFE3 gene fusions (Argani et al. 2010). See Table 5.

\section{Emerging and new entities}

The first three tumors take part in the differential diagnosis of oncocytic tumors and their main distinctive features are reviewed in Table 5.

Low-grade oncocytic tumor of the kidney shares with oncocytomas the predominant solid and nested growth pattern and the oncocytic cytoplasm. However, they show a distinct immunophenotype of c-KIT/CD117 negative and cytokeratin 7 positive. The typical microscopic picture is of solid sheets and compact nests, with gradual transition to trabecular areas, sharply delineated edematous stromal areas with loose cell growth. These loose irregular areas of growth differ from the islands of oncocytic cells in hypocellular areas of oncocytoma. Genomic findings are shared with oncocytomas such as loss of $1 \mathrm{p} 36$ and diploid pattern, while gains and losses that are common in chromophobe RCC are not seen. They exhibit uniformly an indolent course (Trpkov et al. 2019b). Although the authors advocate that low-grade oncocytic tumor of the kidney may be readily recognized in HE stain, we recommend that this diagnosis should be considered in tumors with compatible findings in the context of cKIT/CD117 negative, cytokeratin 7 positive findings when the common differential diagnosis of oncocytoma and chromophobe carcinoma is being evaluated. The importance of recognizing this tumor is to avoid labeling such indolent tumors as unclassified RCC.

High-grade oncocytic tumor of the kidney is also a new diagnostic category of tumors that may be separated soon from the "umbrella" term of unclassified renal cell carcinoma (He et al. 2018). These tumors are predominantly composed of oncocytic cells with high-grade nuclei, and prominent intracytoplasmic vacuoles. At microscopy, they are well-circumscribed, non-encapsulated tumors, that demonstrates solid to nested growth with focal tubulocystic features (Chen et al. 2019). These tumors show a oncocytoma-like immunoprofile: CD117 positive with CK7 only focally positive in scattered cells, however, Cathepsin $\mathrm{K}$ is invariably positive, either as diffuse or focal, and CD10 is also expressed. Most are sporadic but some cases have been associated with tuberous sclerosis (Trpkov et al. 2019a). Genetic alterations include losses of TSC2 and TSC1 and activation of the MTOR pathway. These alterations have also been found in ESC RCC (see below). Despite high-grade nuclear features, these tumors seem to follow an indolent course, although longer follow up is warranted for a more assertive definition of prognosis (Siadat and Trpkov 2020). The main differential diagnosis is with oncocytoma. Oncocytoma may show a broad spectrum of morphologies but a diffuse high-grade morphology is beyond the permissible criteria (Siadat and Trpkov 2020).

Eosinophilic solid and cystic renal cell carcinoma (ESC RCC) was originally described in female patients with tuberous sclerosis, but subsequent reports showed that it also occurs in a sporadic form also with female predominance (Guo et al. 2014; Trpkov et al. 2016a). These tumors are grossly tan alternating solid and cystic areas. At microscopy, the tumor shows eosinophilic and granular cytoplasm. Solid areas exhibit sheets, nests or acini, usually with adjacent cystic areas - with the cyst wall layered by eosinophilic cells. Other common features are intracytoplasmic vacuoles and psammoma bodies (Trpkov et al. 2016b). Typically, these tumors are immunoreactive for cytokeratin 20, PAX 8 and vimentin; and negative for c-KIT and cytokeratin 7. Importantly, the immunophenotype cytokeratin 20 positive and cytokeratin 7 negative is unique among renal cell carcinoma subtypes (Fig. 7). ESC RCC shows genetic changes with gains in 16p13.3-16q23.1, 7p21.2-7q36.2 and 13q14.2, while losses were seen at Xp11.21 and 22q11.23. Loss of heterozygosity was most frequently associated with loci of 16p, 11p, 9q and X (Trpkov et al. 2017). Sporadic cases commonly show mutations on TSC1 and TSC2 genes the genes for which germline mutations are the cause of tuberous sclerosis (Delahunt et al. 2019). Most of these tumors are confined to the kidney and show indolent behavior, although more recently ESC RCC has demonstrated metastatic potential (McKenney et al. 2018).

In a series of 33 unclassified RCCs with predominantly eosinophilic cytoplasm in patients aged 35 years or younger, 10 (30\%) were reclassified as ESC RCCs. The authors suggested that pathologists should have a low threshold for performing CK20 immunohistochemistry when confronted with unclassified eosinophilic RCC or 'oncocytoma' in young patients ( $\mathrm{Li}$ et al. 2018). The incidence is currently unknown, because many of these cases have previously been either misdiagnosed or labelled as 'unclassified renal cell carcinoma' or 'unclassified renal neoplasm with oncocytic or eosinophilic morphology'. 


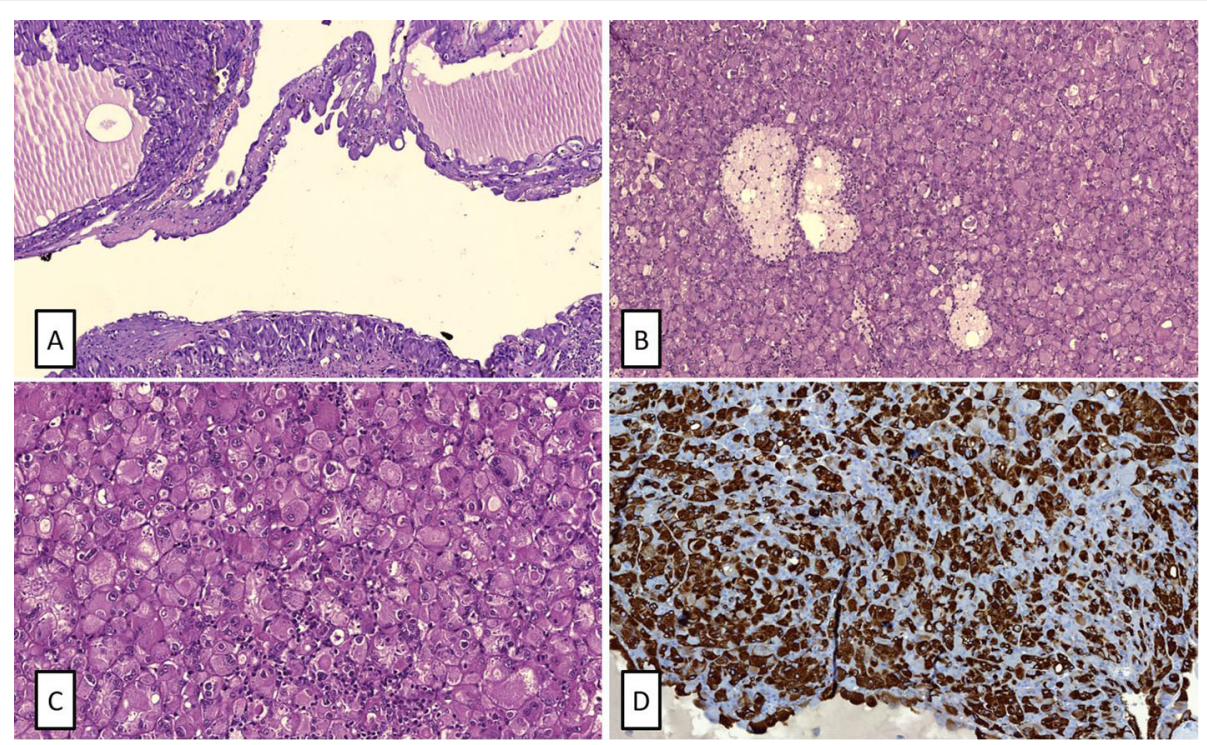

Fig. 7 Eosinophilic, solid and cystic renal cell carcinoma (ESC-RCC). Growth patterns alternate cystic areas (a HE, 40x) and solid areas of oncocytic cells (b and c HE, 40x and 100x). Diffuse staining of cytokeratin 20 (d 40x)

Anaplastic Lymphoma Kinase (ALK) rearrangementsassociated renal cell carcinoma (ALK RCC) are rare with about 30 reported cases. They are usually centered in renal medulla. Original descriptions described cytoskeletal protein vinculin (VCL)-ALK fusions and highlighted large polThese tumors resembled medullary carcinomas and were associated with sickle cell trait (Smith et al. 2014). Other ALK fusions (mainly with tropomyosin 3, TPM3 and echinoderm microtubule associated protein like 4, EML4) may show variable morphology including mucinous cribriform, signet-ring cell pattern, rhabdoid features and mixed cell population resembling Xp11 RCC (Kuroda et al. 2018, 2020). The few reports available suggest an indolent behavior for VCL-ALK rearrangement-associated RCC but some non-VCL related ALK fusion associated RCC present in advance stage (Yu et al. 2017). Target therapy for ALK fusion associated RCC may benefit these patients, but the available literature is limit (Delahunt and Srigley 2015; Pal et al. 2018). It has been recently suggested that ALK RCC may be screened by the immunoprofile of PAX8 and ALK1 (D5F3 clone) expression among unclassified renal cell carcinomas (Kuroda et al. 2020).

Renal cell carcinoma with (angio) leiomyomatous stroma (RCCLMS) is listed as a provisional entity in the 2016 WHO blue book and may raise confusion with other morphologic subtypes RCC. Two indolent tumors - renal angioleiomyomatous tumor and papillary clear cell carcinomas were described in the early 2000's and most of the available data suggest that they are related entities. They share morphologic and immunohistochemical features and are distinguished only by the amount of stroma within the tumor. This angioleiomyomatous stroma is reactive (Petersson et al. 2014) and both tumors share absent VHL gene alterations (Hes et al. 2016). In the current WHO classification, abundant stroma in an otherwise typical clear cell papillary carcinoma is a variant morphology and the term renal angioleiomyomatous tumor is considered a (obsolete) synonym of PCCRCC (Moch et al. 2016). In contrast, RCCLMS is a rare tumor that may show intermixed epithelial and stromal components with distinct features: epithelial areas are mainly low-grade tubular or nested but may show focal papillary and solid growth. Tumor cells shows voluminous clear or light eosinophilic cytoplasm instead of the typical reverse polarity of PCCRCC. Cytokeratin 7 expression is strong and diffuse (by definition) and carbonic anhydrase IX expression may commonly show diffuse membranous or cup-shaped/basolateral patterns (Fig. 8). These tumors commonly harbor somatic TSC1, TSC2, MTOR, TCEB1 gene alterations and intact VHL gene (Shah et al. 2020). The main differential diagnoses of RCCLMS are depicted in Table 2. TCEB1 mutated renal cell carcinoma is being recognized as a distinct entity with common association with chromosome 8 monosomy (Williamson et al. 2020). While most data suggest that RCCLMS are indolent, some recent reports of aggressive cases have been reported for TCEB1 mutated RCCs (Hakimi et al. 2015; DiNatale et al. 2019).

\section{Unclassified renal cell carcinoma}

Unclassified renal cell carcinoma (URCC) is not a distinct subtype but rather a category used for cases that do not fulfill diagnostic criteria for other well-defined entities, being it low- or high-grade. In most series, URCC 


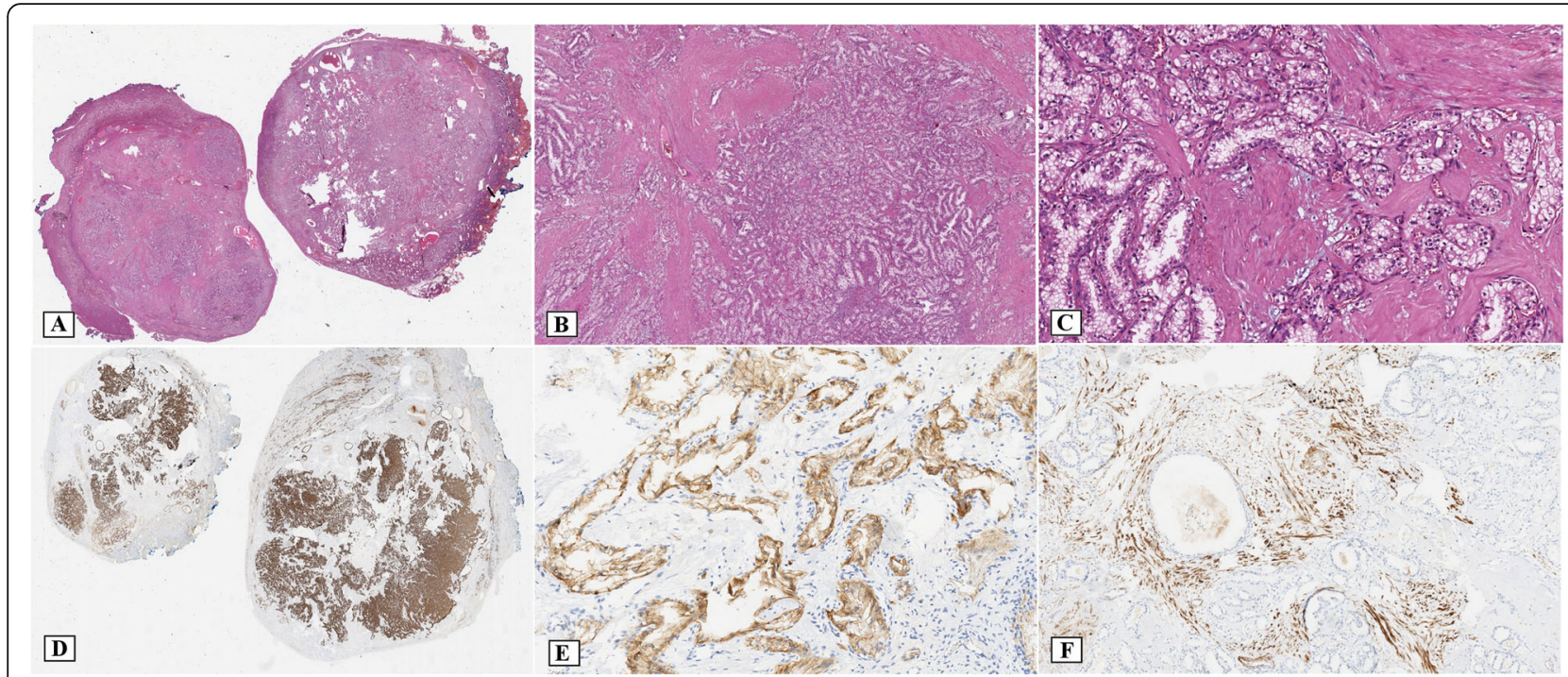

Fig. 8 Renal cell carcinoma with leiomyomatous stroma (RCCLMS). A tumor intermixed epithelial and stromal components (a HE, 2x). Low-grade clear cells growing in tubular pattern separated by abundant stroma with smooth muscle differentiation (b HE, 40x and $\mathbf{c} H E$, 100x). Cytokeratin 7 expression is strong and diffuse (d $2 \mathrm{x}$ ) and carbonic anhydrase IX shows membranous expression (e 100x). The surrounding stroma is reactive for desmin (f 40x)

corresponds to about $5 \%$ of all RCCs after proper workup. Tumors in the following scenarios may also be placed in the unclassified category: tumors that show features of $>1$ different subtype; low- or high-grade unclassified oncocytic/eosinophilic neoplasms; or tumors with pure sarcomatoid morphology (Moch et al. 2016). The most common diagnostic dilemma in daily practice is that of oncocytic / eosinophilic renal neoplasms, which often include oncocytoma in the differential diagnosis (Perrino et al. 2018). However, stringent criteria should be used to render a diagnosis of oncocytoma, given the management implications of a benign diagnosis. In a series of 33 eosinophilic URCC in patients 35 years of age or younger, $67 \%$ of tumors were reclassified into one of the recently defined entities SDH-deficient RCC, FH-deficient RCC and ESC RCC if SDHB, FH / 2-SC, and CK20, respectively, were applied ( $\mathrm{Li}$ et al. 2018). These stains should therefore be included in difficult-to-classify eosinophilic renal tumors, especially in young patients. Other frequent morphologic patterns in which URCC is the rendered diagnosis are those of tumors with predominant papillary architecture and of collecting-duct morphology.

Unclassified RCCs consist of a markedly heterogeneous group of tumors, thus there is no specific immunohistochemical marker/panel. Immunostains to be used depend on which entities are being considered in the differential diagnosis, and it is expected that these cases have been evaluated by a large battery of stains to indicate a specific subtype. As recommended by the ISUP consensus, the category of URCC should not be used until all efforts to classify the tumor have been exhausted (Reuter et al. 2014). Also, at least the renal origin should be proven by PAX8 expression (95\% of renal cell tumors are PAX8 positive), keeping in mind that tumors from nonrenal origin also stain for this marker, and appropriate markers should be included on a case-by-case basis (Reuter et al. 2014). Nonrenal, PAX8-positive tumors include Müllerian, thyroid, thymic, and urothelial carcinoma of the upper urinary tract (20\% in the latter); well-differentiated neuroendocrine tumors of the pancreas; poorly differentiated neuroendocrine carcinomas regardless of site of origin; and B-cell lymphomas (Haynes et al. 2011; Reuter et al. 2014).

As a group, unclassified RCC carries a mortality rate higher than clear cell RCC. However, the heterogeneity of this category cannot be stressed enough, and low grade and low stage tumors are often placed into this category as well (Perrino et al. 2018). A proper pathology report should contain all data necessary to predict biological behavior, such as nuclear grade, stage, extent of necrosis, tumor size, lymphovascular invasion, and presence of rhabdoid/sarcomatoid components.

The correct use of this category is important, especially for future studies. Reevaluating URCCs with emerging molecular tools are often shedding light into new entities that were hitherto unclassified.

\section{Conclusion}

Use of conscientious ancillary tests in renal cell carcinomas may save time and resources in some tumors. The use of the recommendations above will filter those cases that will require large panel of immunostains, specific and not widely available tests (such as TFE3, TFEB, FH and SDHB immunohistochemistry; FISH) or genetic testing. 


\section{Abbreviations}

2SC: 2-succinocysteine; ACKD: Acquired cystic kidney disease; ALK: Anaplastic lymphoma kinase; AMARC: Alpha-methyacyl coenzyme A racemase; BAP1: BRCA1 Associated Protein 1; CA-IX: Carbonic anhydrase IX: CD10: Cluster of differentiation 10; CD57: Cluster of differentiation 57; CD117: Cluster of differentiation 117; CDC: Collecting duct carcinoma; CK7: Cytokeratin 7; CK20: Cytokeratin 20; ESC RCC: Eosinophilic, solid and cystic renal cell carcinoma; FH: Fumarate hydratase; FISH: Fluorescence in situ hybridization; FLCN: Folliculin; GATA3: GATA binding protein 3;

GIST: Gastrointestinal stromal tumor; HLRCC: Hereditary Leiomyomatosis and Renal Cell Carcinoma syndrome; IHC: Immunohistochemistry; ISUP: International Society of Urologic Pathology; MiT: Microphthalmia transcription factor; MTOR: Mammalian target of rapamycin; MTSC C: Mucinous tubular and spindle cell carcinoma; PAX8: Paired box 8; PRCC: Papillary renal cell carcinoma; PRBM1: Polybromo 1; RCC: Renal cell carcinoma; RCCLMS: Renal cell carcinoma with (angio) leiomyomatous stroma; SDH: Succinate dehydrogenase; SMARCB1: SWI/SNF Related, Matrix Associated, Actin Dependent Regulator Of Chromatin, Subfamily B, Membe 1; TFE3: Transcription Factor E3; TFEB: Transcription Factor EB; TSC1: TSC Complex Subunit 1; TSC2: TSC Complex Subunit 2; URCC: Unclassified renal cell carcinoma; VHL: von Hippel-Lindau; WHO: World Health Organization; WT1: Wilms' tumour 1

\section{Acknowledgements}

We are grateful to Dr. Igor Campos da Silva, Department of Specialties, Brazilian Society of Pathology.

\section{Authors' contributions}

DAA conceived the idea. DAA, LSA, ARP, SFF, FRFT and MSC were major contributors to the writing of the manuscript. All authors were major contributors for critically revising the manuscript for important intellectual content. All authors read and approved the final manuscript.

\section{Funding}

This study had no funding resources.

\section{Availability of data and materials}

Not applicable.

\section{Ethics approval and consent to participate}

Not applicable.

\section{Consent for publication}

Not applicable.

\section{Competing interests}

The authors declare that they have no competing interests.

\section{Author details}

${ }^{1}$ Hospital Universitário Professor Edgard Santos / Universidade Federal da Bahia, Salvador, Brazil. ${ }^{2}$ magepat, Laboratory of Pathology, Salvador, Brazil. ${ }^{3}$ Instituto de Anatomia Patológica, Americana, Piracicaba \& Santa Bárbara d'Oeste, Brazil. ${ }^{4}$ Department of Pathology, Rede D'Or/São Luiz Hospital, São Paulo, Brazil. ${ }^{5}$ Faculdade de Medicina da Universidade de São Paulo, São Paulo, Brazil. ${ }^{6}$ Hospital Napoleão Laureano, João Pessoa, Brazil. ${ }^{7}$ Universidade Federal da Paraíba, João Pessoa, Brazil. ${ }^{8}$ CPD Citologia e Patologia Diagnóstica, Curitiba, Brazil. ${ }^{9}$ Pathology Department, Hospital do Trabalhador, Curitiba, Brazil. ${ }^{10}$ Instituto Médico Legal de Ponta Grossa, IMLPG, Ponta Grossa, Brazil. ${ }^{11}$ Argos Laboratory, Fortaleza, Brazil. ${ }^{12}$ Universidade Federal do Ceará, Fortaleza, Brazil. ${ }^{13}$ Pathology Department, Hospital Israelita Albert Einstein, São Paulo, Brazil. ${ }^{14}$ Pathology Department, Instituto do Cancer do Estado de Sao Paulo, São Paulo, Brazil. ${ }^{15}$ Neopath Patologia Diagnóstica, Curitiba, Brazil. ${ }^{16}$ Department of Pathology, Hospital Universitário Evangélico Mackenzie, Curitiba, Brazil. ${ }^{17}$ Department of Anatomic Pathology, A.C.Camargo Cancer Center, Sao Paulo, Brazil.
Received: 13 October 2020 Accepted: 21 December 2020

Published online: 01 February 2021

\section{References}

Adam J, Couturier J, Molinié V, Vieillefond A, Sibony M (2011) Clear-cell papillary renal cell carcinoma: 24 cases of a distinct low-grade renal tumour and a comparative genomic hybridization array study of seven cases. Histopathology 58:1064-1071

Alaghehbandan R, Ulamec M, Martinek P, Pivovarcikova K, Michalova K, Skenderi F, Hora M, Michal M, Hes O (2019) Papillary pattern in clear cell renal cell carcinoma: clinicopathologic, morphologic, immunohistochemical and molecular genetic analysis of 23 cases. Ann Diagn Pathol 38:80-86

Al-Obaidy Kl, Eble JN, Cheng L, Williamson SR, Sakr WA, Gupta N, Idrees MT, Grignon DJ (2019) Papillary renal neoplasm with reverse polarity: a morphologic, immunohistochemical, and molecular study. Am J Surg Pathol 43:1099-1111

Amin MB, Amin MB, Tamboli P, Javidan J, Stricker $\mathrm{H}$, de-Peralta Venturina M, Deshpande A, Menon M (2002) Prognostic impact of histologic subtyping of adult renal epithelial neoplasms: an experience of 405 cases. Am J Surg Pathol 26:281-291

Argani P, Aulmann S, Illei PB, Netto GJ, Ro J, Cho HY, Dogan S, Ladanyi M, Martignoni G, Goldblum JR, Weiss SW (2010) A distinctive subset of PEComas harbors TFE3 gene fusions. Am J Surg Pathol 34:1395-1406

Argani P, Netto GJ, Parwani AV (2008) Papillary renal cell carcinoma with lowgrade spindle cell foci - a mimic of mucinous tubular and spindle cell carcinoma. Am J Surg Pathol 32:1353-1359

Argani P, Olgac S, Tickoo SK, Goldfischer M, Moch H, Chan DY, Eble JN, Bonsib SM, Jimeno M, Lloreta J, Billis A, Hicks J, De Marzo AM, Reuter VE, Ladanyi M (2007) Xp11 translocation renal cell carcinoma in adults: expanded clinical, pathologic, and genetic spectrum. Am J Surg Pathol 31:1149-1160

Aron M, Chang E, Herrera L, Hes O, Hirsch MS, Comperat E, Camparo P, Rao P, Picken M, Michal M, Montironi R, Tamboli P, Monzon F, Amin MB (2015) Clear cell-papillary renal cell carcinoma of the kidney not associated with end-stage renal disease: clinicopathologic correlation with expanded immunophenotypic and molecular characterization of a large cohort with emphasis on relationship with renal angiomyoadenomatous tumor. Am J Surg Pathol 39:873-888

Aydin H, Chen L, Cheng L, Vaziri S, He H, Ganapathi R, Delahunt B, Magi-Galluzzi C, Zhou M (2010) Clear cell tubulopapillary renal cell carcinoma: a study of 36 distinctive low-grade epithelial tumors of the kidney. Am J Surg Pathol 34:1608-1621

Bhatnagar R, Alexiev BA (2012) Renal-cell carcinomas in end-stage kidneys: a clinicopathological study with emphasis on clear-cell papillary renal-cell carcinoma and acquired cystic kidney disease-associated carcinoma. Int $J$ Surg Pathol 20:19-28

Brimo F, Atallah C, Li G, Srigley JR (2016) Cystic clear cell papillary renal cell carcinoma: is it related to multilocular clear cell cystic neoplasm of low malignant potential? Histopathology 68:666-672

Bulimbasic S, Ljubanovic D, Sima R, Michael M, Hes O, Kuroda N, Persec Z (2009) Aggressive high-grade mucinous tubular and spindle cell carcinoma. Hum Pathol 40:906-907

Caliò A, Brunelli M, Segala D, Pedron S, Remo A, Ammendola S, Munari E, Pierconti F, Mosca A, Bollito E, Sidoni A, Fisogni S, Sacco C, Canu L, Sentinelli S, Fraccon AP, Fiorentino M, Scott C, Milella M, Porta C, Argani P, Martignoni G (2020) Comprehensive analysis of 34 MiT family translocation renal cell carcinomas and review of the literature: investigating prognostic markers and therapy targets. Pathology 52:297-309

Caliò A, Segala D, Munari E, Brunelli M, Martignoni G (2019) MiT family translocation renal cell carcinoma: from the early descriptions to the current knowledge. Cancers (Basel) 11(8):110

Cancer Genome Atlas Research Network, Linehan WM, Spellman PT et al (2016) Comprehensive molecular characterization of papillary renal-cell carcinoma. N Engl J Med 374:135-145

Chen Y, Mirsadraei L, Jayakumaran G, Al-Ahmadie H, Fine S, Gopalan A Sirintrapun SJ, Tickoo S, Reuter V (2019) Somatic mutations of TSC2 or MTOR characterize a morphologically distinct subset of sporadic renal cell carcinoma with eosinophilic and vacuolated cytoplasm. Am J Surg Pathol 43: $121-131$

Chevarie-Davis M, Riazalhosseini Y, Arseneault M, Aprikian A, Kassouf W, Tanguay S, Latour M, Brimo F (2014) The morphologic and immunohistochemical spectrum of papillary renal cell carcinoma: study including 132 cases with 
pure type 1 and type 2 morphology as well as tumors with overlapping features. Am J Surg Pathol 38:887-894

Delahunt B, Cheville JC, Martignoni G, Humphrey PA, Magi-Galluzzi C, McKenney J, Egevad L, Algaba F, Moch H, Grignon DJ, Montironi R, Srigley JR, Members of the ISUP Renal Tumor Panel (2013) The International Society of Urological Pathology (ISUP) grading system for renal cell carcinoma and other prognostic parameters. Am J Surg Pathol 37:1490-1504

Delahunt B, Eble JN, Egevad L, Yahley J, Thunders M, Samaratunga H (2019) Emerging entities of renal cell neoplasia. Surg Exp Pathol 2:10. https://doi. org/10.1186/s42047-019-0035-x

Delahunt B, Srigley JR (2015) The evolving classification of renal cell neoplasia. Semin Diagn Pathol 32:90-102

Dhakal HP, McKenney JK, Khor LY, Reynolds JP, Magi-Galluzzi C, Przybycin CG (2016) Renal neoplasms with overlapping features of clear cell renal cell carcinoma and clear cell papillary renal cell carcinoma: a clinicopathologic study of 37 cases from a single institution. Am J Surg Pathol 40:141-154

DiNatale RG, Gorelick AN, Makarov V, Blum KA, Silagy AW, Freeman B, Chowell D, Marcon J, Mano R, Sanchez A, Attalla K, Weng S, Voss M, Motzer RJ, Russo P, Coleman JA, Reuter VE, Chen YB, Chan TA, Reznik E, Tickoo SK, Hakimi AA (2019) Putative drivers of aggressiveness in TCEB1-mutant renal cell carcinoma: an emerging entity with variable clinical course. Eur Urol Focus: S2405-4569(19)30354-2. https://doi.org/10.1016/j.euf.2019.11.013

Epstein JI, Netto GJ (2014) Differential diagnoses in surgical pathology genitourinary system. Lippincott Williams and Wilkins, Philadelphia, pp 200 202

Fine SW, Argani P, DeMarzo AM, Delahunt B, Sebo TJ, Reuter VE, Epstein II (2006) Expanding the histologic spectrum of mucinous tubular and spindle cell carcinoma of the kidney. Am J Surg Pathol 30:1554-1560

Flum AS, Hamoui N, Said MA, Yang XJ, Casalino DD, McGuire BB, Perry KT, Nadler RB (2016) Update on the diagnosis and management of renal angiomyolipoma. J Urol 195(4 Pt 1):834-846

Gill AJ (2012) Use of SDHB immunohistochemistry to identify germline mutations of SDH genes. Hered Cancer Clin Pract 10(Suppl 2):A7

Gill AJ, Pachter NS, Chou A, Young B, Clarkson A, Tucker KM, Winship IM, Earls P, Benn DE, Robinson BG, Fleming S, Clifton-Bligh RJ (2011) Renal tumors associated with germline SDHB mutation show distinctive morphology. Am J Surg Pathol 35:1578-1585

Giunchi F, Gruppioni E, Altimari A, Capizzi E, Massari F, Schiavina R, Brunelli M, Martignoni G, Fiorentino M (2020) Similarities and differences between clear cell tubulo-papillary and conventional clear cell renal cell carcinoma: a comparative phenotypical and mutational analysis. Diagnostics (Basel) 10(2): 123

Green WM, Yonescu R, Morsberger L, Morris K, Netto GJ, Epstein Jl, Illei PB, Allaf M, Ladanyi M, Griffin CA, Argani P (2013) Utilization of a TFE3 break-apart FISH assay in a renal tumor consultation service. Am J Surg Pathol 37:11501163

Guo J, Tretiakova MS, Troxell ML, Osunkoya AO, Fadare O, Sangoi AR, Shen SS, Lopez-Beltran A, Mehra R, Heider A, Higgins JP, Harik LR, Leroy X, Gill AJ, Trpkov K, Campbell SC, Przybycin C, Magi-Galluzzi C, McKenney JK (2014) Tuberous sclerosis-associated renal cell carcinoma: a clinicopathologic study of 57 separate carcinomas in 18 patients. Am J Surg Pathol 38:1457-1467

Gupta S, Swanson AA, Chen YB, Lopez T, Milosevic D, Kipp BR, Leibovich BC, Thompson RH, Herrera-Hernandez L, Cheville JC, Jimenez RE (2019) Incidence of succinate dehydrogenase and fumarate hydratase-deficient renal cell carcinoma based on immunohistochemical screening with SDHA/SDHB and FH/2SC. Hum Pathol 91:114-122

Hakimi AA, Tickoo SK, Jacobsen A, Sarungbam J, Sfakianos JP, Sato Y, Morikawa T, Kume H, Fukayama M, Homma Y, Chen YB, Sankin A, Mano R, Coleman JA, Russo P, Ogawa S, Sander C, Hsieh JJ, Reuter VE (2015) TCEB1-mutated renal cell carcinoma: a distinct genomic and morphological subtype. Mod Pathol 28:845-853

Haynes CM, Sangoi AR, Pai RK (2011) PAX8 is expressed in pancreatic welldifferentiated neuroendocrine tumors and in extrapancreatic poorly differentiated neuroendocrine carcinomas in fine-needle aspiration biopsy specimens. Cancer Cytopathol 119:193-201

He H, Trpkov K, Martinek P, Isikci OT, Maggi-Galuzzi C, Alaghehbandan R, Gill AJ, Tretiakova M, Lopez Jl, Williamson SR, Montiel DP, Sperga M, Comperat E, Brimo F, Yilmaz A, Pivovarcikova K, Michalova K, Slouka D, Prochazkova K, Hora M, Bonert M, Michal M, Hes O (2018) "High-grade oncocytic renal tumor": morphologic, immunohistochemical, and molecular genetic study of 14 cases. Virchows Arch 473:725-738
Hes O, Compérat EM, Rioux-Leclercq N (2016) Clear cell papillary renal cell carcinoma, renal angiomyoadenomatous tumor, and renal cell carcinoma with leiomyomatous stroma relationship of 3 types of renal tumors: a review. Ann Diagn Pathol 21:59-64

Kim SS, Cho YM, Kim GH, Kee KH, Kim HS, Kim KM, Kim JH, Choi C (2020) Recurrent KRAS mutations identified in papillary renal neoplasm with reverse polarity-a comparative study with papillary renal cell carcinoma. Mod Pathol 33:690-699.31953522

Kryvenko ON, Jorda M, Argani P, Epstein JI (2014) Diagnostic approach to eosinophilic renal neoplasms. Arch Pathol Lab Med 138:1531-1541

Kuroda N, Hes O, Michal M, Nemcova J, Gal V, Yamaguchi T, Kawada T, Imamura Y, Hayashi Y, Lee GH (2008) Mucinous tubular and spindle cell carcinoma with Fuhrman nuclear grade 3: a histological, immunohistochemical, ultrastructural and FISH study. Histol Histopathol 23:1517-1523

Kuroda N, Ohe C, Kawakami F, Mikami S, Furuya M, Matsuura K, Moriyama M, Nagashima Y, Zhou M, Petersson F, López Jl, Hes O, Michal M, Amin MB (2014) Clear cell papillary renal cell carcinoma: a review. Int J Clin Exp Pathol 7:7312-7318

Kuroda N, Sugawara E, Kusano H, Yuba Y, Yorita K, Takeuchi K (2018) A review of ALK-rearranged renal cell carcinomas with a focus on clinical and pathobiological aspects. Pol J Pathol 69:109-113

Kuroda N, Trpkov K, Gao, Tretiakova M, Liu YJ, Ulamec M, Takeuchi K, Agaimy A, Przybycin C, Magi-Galluzzi C, Fushimi S, Kojima F, Sibony M, Hang JF, Pan CC, Yilmaz A, Siadat F, Sugawara E, Just PA, Ptakova N, Hes O (2020) ALK rearranged renal cell carcinoma (ALK-RCC): a multi-institutional study of twelve cases with identification of novel partner genes CLIP1, KIF5B and KIAA1217. Mod Pathol. https://doi.org/10.1038/s41379-020-0578-0

Kuthi L, Somorácz Á, Micsik T, Jenei A, Hajdu A, Sejben I, Imre D, Pósfai B, Kóczián K, Semjén D, Bajory Z, Kulka J, Iványi B (2020) Clinicopathological findings on 28 cases with XP11.2 renal cell carcinoma. Pathol Oncol Res 26:2123-2133

Li Y, Reuter VE, Matoso A, Netto GJ, Epstein Jl, Argani P (2018) Re-evaluation of 33 'unclassified' eosinophilic renal cell carcinomas in young patients. Histopathology 72:588-600

Linehan WM (2013) Evaluation and screening for hereditary renal cell cancers. Can Urol Assoc J 7(9-10):324-325

Mai KT, Kohler DM, Belanger EC, Robertson SJ, Wang D (2008) Sporadic clear cell renal cell carcinoma with diffuse cytokeratin 7 immunoreactivity. Pathology 40:481-486

Mantilla JG, Antic T, Tretiakova M (2017) GATA3 as a valuable marker to distinguish clear cell papillary renal cell carcinomas from morphologic mimics. Hum Pathol 66:152-158

Massari F, Ciccarese C, Hes O, Michal M, Caliò A, Fiorentino M, Giunchi F, D'Amuri A, Sanguedolce F, Sabbatini R, Guida A, Ardizzoni A, Porta C, lacovelli R, Tortora G, Cima L, Ortega C, Lapini A, Martignoni G, Brunelli M (2018) The tumor entity denominated "clear cell-papillary renal cell carcinoma" according to the WHO 2016 new classification, have the clinical characters of a renal cell adenoma as does harbor a benign outcome. Pathol Oncol Res 24:447-456

McDaniel AS, Chinnaiyan AM, Siddiqui J, McKenney JK, Mehra R (2014) Immunohistochemical staining characteristics of nephrogenic adenoma using the PIN-4 cocktail (p63, AMACR, and CK903) and GATA-3. Am J Surg Pathol 38:1664-1671

McKenney JK, Przybycin CG, Trpkov K, Magi-Galluzzi C (2018) Eosinophilic solid and cystic renal cell carcinomas have metastatic potential. Histopathology 72:1066-1067

Moch H, Humphrey PA, Ulbright TM, Reuter V (2016) WHO classification of tumours of the urinary system and male genital organs. International Agency for Research on Cancer, Lyon

Murugan P, Chen Y, Al-Ahmadie H et al (2014) Type 1 papillary renal cell carcinoma: a contemporary study addressing classification, clinicopathologic features and treatment outcome. Genitourinary Pathology. Mod Pathol 27: 212-273 Abstract 1034, USCAP 103rd Annual Meeting Abstracts

Ohe C, Smith SC, Sirohi D, Divatia M, de Peralta-Venturina M, Paner GP, Agaimy $A$, Amin MB, Argani $P$, Chen $Y B$, Cheng $L$, Colecchia $M$, Compérat $E$, Werneck da Cunha I, Epstein JI, Gill AJ, Hes O, Hirsch MS, Jochum W, Kunju LP, Maclean F, Magi-Galluzzi C, McKenney JK, Mehra R, Nesi G, Osunkoya AO, Picken MM, Rao P, Reuter VE, de Oliveira Salles PG, Schultz L, Tickoo SK, Tomlins SA, Trpkov K, Amin MB (2018) Reappraisal of morphologic differences between renal medullary carcinoma, collecting duct carcinoma, and fumarate hydratase-deficient renal cell carcinoma. Am J Surg Pathol 42: 279-292 
Ornstein DK, Lubensky IA, Venzon D, Zbar B, Linehan WM, Walther MM (2000) Prevalence of microscopic tumors in normal appearing renal parenchyma of patients with hereditary papillary renal cancer. J Urol 163:431-433

Pal SK, Bergerot P, Dizman N, Bergerot C, Adashek J, Madison R, Chung JH, Ali SM, Jones JO, Salgia R (2018) Responses to Alectinib in ALK-rearranged papillary renal cell carcinoma. Eur Urol 74:124-128

Perrino CM, Grignon DJ, Williamson SR, Idrees MT, Eble JN, Cheng L (2018) Morphological spectrum of renal cell carcinoma, unclassified: an analysis of 136 cases. Histopathology 72:305-319

Petersson F, Branzovsky J, Martinek P, Korabecna M, Kruslin B, Hora M, Peckova K, Bauleth K, Pivovarcikova K, Michal M, Svajdler M, Sperga M, Bulimbasic S, Leroy X, Rychly B, Trivunic S, Kokoskova B, Rotterova P, Podhola M, Suster S, Hes $O$ (2014) The leiomyomatous stroma in renal cell carcinomas is polyclonal and not part of the neoplastic process. Virchows Arch 465:89-96

Pinto A, Signoretti S, Hirsch MS, Barletta JA (2015) Immunohistochemical staining for BRAF V600E supports the diagnosis of metanephric adenoma. Histopathology 66:901-904

Ren Q, Wang L, Al-Ahmadie HA, Fine SW, Gopalan A, Sirintrapun SJ, Tickoo SK, Reuter VE, Chen YB (2018) Distinct genomic copy number alterations distinguish mucinous tubular and spindle cell carcinoma of the kidney from papillary renal cell carcinoma with overlapping histologic features. Am J Surg Pathol 42:767-777

Renshaw AA, Zhang H, Corless CL, Fletcher JA, Pins MR (1997) Solid variants of papillary (chromophil) renal cell carcinoma: clinicopathologic and genetic features. Am J Surg Pathol 21:1203-1209

Reuter VE, Argani P, Zhou M, Delahunt B, Members of the ISUP Immunohistochemistry in Diagnostic Urologic Pathology Group (2014) Best practices recommendations in the application of immunohistochemistry in the kidney tumors: report from the International Society of Urologic Pathology consensus conference. Am J Surg Pathol 38:e35-e49

Ritterhouse LL, Barletta JA (2015) BRAF V600E mutation-specific antibody: a review. Semin Diagn Pathol 32:400-408

Shah RB, Stohr BA, Tu ZJ, Gao Y, Przybycin CG, Nguyen J, Cox RM, Rashid-Kolvear F, Weindel MD, Farkas DH, Trpkov K, McKenney JK (2020) "Renal cell carcinoma with leiomyomatous stroma" harbor somatic mutations of TSC1, TSC2, MTOR, and/or ELOC (TCEB1): clinicopathologic and molecular characterization of 18 sporadic tumors supports a distinct entity. Am J Surg Pathol 44:571-581

Siadat F, Trpkov K (2020) ESC, ALK, HOT and LOT: three letter acronyms of emerging renal entities knocking on the door of the WHO classification. Cancers (Basel) 12:168

Sirohi D, Smith SC, Ohe C, Colombo P, Divatia M, Dragoescu E, Rao P, Hirsch MS, Chen YB, Mehra R, Amin MB (2017) Renal cell carcinoma, unclassified with medullary phenotype: poorly differentiated adenocarcinomas overlapping with renal medullary carcinoma. Hum Pathol 67:134-145

Smith NE, Deyrup AT, Mariño-Enriquez A, Fletcher JA, Bridge JA, Illei PB, Netto GJ, Argani P (2014) VCL-ALK renal cell carcinoma in children with sickle-cell trait: the eighth sickle-cell nephropathy? Am J Surg Pathol 38:858-863

Smith SC, Trpkov K, Chen YB, Mehra R, Sirohi D, Ohe C, Cani AK, Hovelson DH, Omata K, McHugh JB, Jochum W, Colecchia M, Amin M, Divatia MK, Hes O, Menon S, Werneck da Cunha I, Tripodi S, Brimo F, Gill AJ, Osunkoya AO, Magi-Galluzzi C, Sibony M, Williamson SR, Nesi G, Picken MM, Maclean F, Agaimy A, Cheng L, Epstein Jl, Reuter VE, Tickoo SK, Tomlins SA, Amin MB (2016) Tubulocystic carcinoma of the kidney with poorly differentiated foci: a frequent morphologic pattern of fumarate hydratase-deficient renal cell carcinoma. Am J Surg Pathol 40:1457-1472

Srigley JR, Delahunt B, Eble JN, Egevad L, Epstein Jl, Grignon D, Hes O, Moch H, Montironi R, Tickoo SK, Zhou M, Argani P; ISUP Renal Tumor Panel (2013) The International Society of Urological Pathology (ISUP) Vancouver Classification of Renal Neoplasia. Am J Surg Pathol 37:1469-89

Suzigan S, López-Beltrán A, Montironi R, Drut R, Romero A, Hayashi T, Gentili ALC, Fonseca PSP, de Torres I, Billis A, Japp LC, Bollito E, Algaba F, Requena-Tapias MJ (2006) Multilocular cystic renal cell carcinoma: a report of 45 cases of a kidney tumor of low malignant potential. Am J Clin Pathol 125:217-222

Tan PH, Cheng L, Rioux-Leclercq N, Merino MJ, Netto G, Reuter VE, Shen SS, Grignon DJ, Montironi R, Egevad L, Srigley JR, Delahunt B, Moch H, ISUP Renal Tumor Panel (2013) Renal tumors: diagnostic and prognostic biomarkers. Am J Surg Pathol 37:1518-1531

Tickoo SK, Chen YB, Zynger DL (2015) Biopsy interpretation of the kidney \& adrenal gland, 1st edn. Lippincott Williams and Wilkins, Philadelphia
Tickoo SK, de Peralta-Venturina MN, Harik LR, Worcester HD, Salama ME, Young AN, Moch H, Amin MB (2006) Spectrum of epithelial neoplasms in end-stage renal disease: an experience from 66 tumor-bearing kidneys with emphasis on histologic patterns distinct from those in sporadic adult renal neoplasia. Am J Surg Pathol 30:141-153

Trpkov K, Abou-Ouf H, Hes O, Lopez Jl, Nesi G, Comperat E, Sibony M, Osunkoya AO, Zhou M, Gokden N, Leroy X, Berney DM, Werneck Cunha I, Musto ML, Athanazio DA, Yilmaz A, Donnelly B, Hyndman E, Gill AJ, McKenney JK, Bismar TA (2017) Eosinophilic solid and cystic renal cell carcinoma (ESC RCC): further morphologic and molecular characterization of ESC RCC as a distinct entity. Am J Surg Pathol 41:1299-1308

Trpkov K, Bonert M, Gao Y, Kapoor A, He H, Yilmaz A, Gill AJ, Williamson SR, Comperat E, Tretiakova M, Magi-Galluzzi C, Brimo F, Hes O (2019a) Highgrade oncocytic tumour (HOT) of kidney in a patient with tuberous sclerosis complex. Histopathology 75:440-442

Trpkov K, Hes O (2019) New and emerging renal entities: a perspective postWHO 2016 classification. Histopathology 74:31-59

Trpkov K, Hes O, Agaimy A, Bonert M, Martinek P, Magi-Galluzzi C, Kristiansen G, Lüders C, Nesi G, Compérat E, Sibony M, Berney DM, Mehra R, Brimo F, Hartmann A, Husain A, Frizzell N, Hills K, Maclean F, Srinivasan B, Gill AJ (2016b) Fumarate hydratase-deficient renal cell carcinoma is strongly correlated with fumarate hydratase mutation and hereditary Leiomyomatosis and renal cell carcinoma syndrome. Am J Surg Pathol 40:865-875

Trpkov K, Hes O, Bonert M, Lopez Jl, Bonsib SM, Nesi G, Comperat E, Sibony M, Berney DM, Martinek P, Bulimbasic S, Suster S, Sangoi A, Yilmaz A, Higgins JP, Zhou M, Gill AJ, Przybycin CG, Magi-Galluzzi C, McKenney JK (2016a) Eosinophilic, solid, and cystic renal cell carcinoma: clinicopathologic study of 16 unique, sporadic neoplasms occurring in women. Am J Surg Pathol 40: 60-71

Trpkov K, Siadat F (2019) Immunohistochemical screening for the diagnosis of succinate dehydrogenase-deficient renal cell carcinoma and fumarate hydratase-deficient renal cell carcinoma. Ann Transl Med 7(Suppl 8):S324

Trpkov K, Williamson SR, Gao Y, Martinek P, Cheng L, Sangoi AR, Yilmaz A, Wang C, San Miguel Fraile P, Perez Montiel DM, Bulimbasić S, Rogala J, Hes O (2019b) Low-grade oncocytic tumour of kidney (CD117-negative, cytokeratin 7-positive): a distinct entity? Histopathology 75:174-184

Trpkov K, Yilmaz A, Uzer D, Dishongh KM, Quick CM, Bismar TA, Gokden N (2010) Renal oncocytoma revisited: a clinicopathological study of 109 cases with emphasis on problematic diagnostic features. Histopathology 57:893-906

Udager AM, Pan J, Magers MJ, Palapattu GS, Morgan TM, Montgomery JS, Weizer AZ, Hafez KS, Miller DC, Wolf JS Jr, MCHugh JB, Chinnaiyan AM, Dhanasekaran SM, Mehra R (2015) Molecular and immunohistochemical characterization reveals novel BRAF mutations in metanephric adenoma. Am J Surg Pathol 39:549-557

Williamson SR, Eble JN, Amin MB, Gupta NS, Smith SC, Sholl LM, Montironi R, Hirsch MS, Hornick JL (2015) Succinate dehydrogenase-deficient renal cell carcinoma: detailed characterization of 11 tumors defining a unique subtype of renal cell carcinoma. Mod Pathol 28:80-94

Williamson SR, Gill AJ, Argani P, Chen YB, Egevad L, Kristiansen G, Grignon DJ, Hes O (2020) Report from the International Society of Urological Pathology (ISUP) consultation conference on molecular pathology of urogenital cancers: III: molecular pathology of kidney cancer. Am J Surg Pathol 44:e47e65

Yu W, Wang Y, Jiang Y, Zhang W, Li Y (2017) Genetic analysis and clinicopathological features of ALK-rearranged renal cell carcinoma in a large series of resected Chinese renal cell carcinoma patients and literature review. Histopathology 71:53-62

Zhou M, Magi-Galluzi C (2015) Genitourinary pathology, 2nd edn. Elsevier, Philadelphia, p 324

\section{Publisher's Note}

Springer Nature remains neutral with regard to jurisdictional claims in published maps and institutional affiliations. 